\title{
Colorimetric metal ion (II) Sensors Based on imine boronic esters
}

\section{functionalized with pyridine}

\author{
Paola Sánchez-Portillo ${ }^{\text {a, * }}$, Aime Hernández-Sirio ${ }^{a}$, Carolina Godoy-Alcántar ${ }^{a}$, \\ Pascal G. Lacroix , Vivechana Agarwal , Rosa Santillán , Victor Barba \\ a Centro de Investigaciones Químicas-IICBA, Universidad Autónoma Del Estado de Morelos, Av. Universidad 1001, C.P. 62209, Cuernavaca, Morelos, Mexico \\ ${ }^{\mathrm{b}}$ CNRS, LCC (Laboratoire de Chimie de Coordination), 2 05, Route de Narbonne, Toulouse, F-31077, France \\ ${ }^{c}$ Centro de Investigación en Ingeniería y Ciencias Aplicadas-IICBA, Universidad Autónoma Del Estado de Morelos Av. Universidad 1001, C.P. 62209, Cuernavaca, \\ Morelos, Mexico \\ ${ }^{\mathrm{d}}$ Departamento de Química, Centro de Investigación y de Estudios Avanzados Del IPN, 07000, Ciudad de México, Mexico
}

\section{A R T I C L E I N F O}

\section{Keywords:}

Colorimetric chemosensors

Boronic esters

Imines

Selective sensors

\begin{abstract}
A B S T R A C T
The one-step synthesis of three imine boronic esters functionalized with pyridyl groups is described (1a-1c). The presence or absence of a methyl group affects the whole conformation, being bent "L" or linear as determined by X-ray crystal diffraction. $\mathrm{C}-\mathrm{H} \cdots \mathrm{O}, \mathrm{C}-\mathrm{H} \cdots \mathrm{N}, \mathrm{C}-\mathrm{H} \cdots \mathrm{F}$ and $\mathrm{C}-\mathrm{H} \ldots \pi$ hydrogen bond interactions support 2D supramolecular arrangements. Ligands were tested as metal ion $\left(\mathrm{M}^{2+}\right)$ sensors in solution. The addition of metal cations $\left(\mathrm{Fe}^{2+}, \mathrm{Co}^{2+}\right.$ and $\left.\mathrm{Cu}^{2+}\right)$ to $1 \mathrm{a}$ using methanol as solvent, showed significant color changes (purple, orange and green, respectively), while for metal cations $\mathrm{Ni}^{2+}, \mathrm{Zn}^{2+}, \mathrm{Cd}^{2+}$ cations no color changes were observed. The sensitivity of compound $\mathbf{1 a}$ towards $\mathrm{Fe}^{2+}, \mathrm{Co}^{2+}$ and $\mathrm{Cu}^{2+}$ was monitored by UV-Vis spectroscopy, where the presence of $\mathrm{Fe}^{2+}$ produces new bands at 360 and $566 \mathrm{~nm}$. For $\mathrm{Co}^{2+}$ and $\mathrm{Cu}^{2+}$ a remarkable intensity increase was observed at $290 \mathrm{~nm}$ band and new bands appear at 340 and $462 \mathrm{~nm}$, respectively. The stoichiometry of the complexes $\mathbf{1 a}-\mathrm{Fe}^{2+}, \mathbf{1} \mathbf{a}-\mathrm{Co}^{2+}$ and $\mathbf{1 a}-\mathrm{Cu}^{2+}$ was determined by Job's plots being 1:3 (metal:ligand, complex [Fe $\left.(1 \mathrm{a})_{3}\right]^{2+}$ ), in contrast with the stoichiometry $1: 1$ observed for $1 \mathrm{~b}-\mathrm{Fe}^{2+}$. In fact, the computed $\Delta \mathrm{G}$ formation associated value showed a strong stabilization for the complex $\left[\mathrm{Fe}(1 \mathrm{a})_{3}\right]^{2+}(-65.5 \mathrm{kcal} / \mathrm{mol})$ in comparison with the possible complex $\left[\mathrm{Fe}(\mathbf{1 b})_{3}\right]^{2+}(-29.7 \mathrm{kcal} / \mathrm{mol})$. Detection limits are in the $\mathrm{mM}$ range (determined by $\mathrm{UV}-\mathrm{Vis}$ ) and $\mu \mathrm{M}$ range (determined by Fluorescence). An analogous bis-bidentate derivative (2a) also shows similar behavior but stoichiometric interaction changes to 2:3 (metal:ligand) and detection limits are in the $\mathrm{mM}$ range obtained by UV-Vis and Fluorescence techniques.
\end{abstract}

\section{Introduction}

Boronic acids have been widely used as building blocks for selfassembly processes [1] but also have attracted interest in sensing methods [2,3]. Boronic acids are easily condensed with 1,2 and 1,3 diols to give rise to the formation of 5- or 6-membered cyclic boronic esters, respectively $[1,4,5]$. One interesting characteristics for these compounds is the Lewis acid character of the tricoordinated boron atom, which can form adducts by interaction with Lewis bases [6,7]. The above reactivity has been used for the construction of species of different nature, such as macrocycles [1,4,8,9] and polymers [7-9], even, more recently the formation of metal-organic species has been possible from the combination with coordinating groups such as Schiff bases and pyridyl groups [10-12].

In addition, Schiff bases have been used as sensors for metal cations, mainly because of the easy formation of the $\mathrm{N} \rightarrow \mathrm{M}$ coordination bonds together with the chelate effect, thus, high selectivity and sensitivity for heavy and transition metal ions is obtained [13-16]. Over the last years, they have received considerable research attention because of their important applications in biological, industrial and environmental processes as chemical sensors [17-21]. Schiff bases are an important type of colorimetric chemosensors because their interaction with analytes can be detected by naked eye, without the use of expensive equipment [22-24] It is well known that for colorimetric chemosensors, the shifts at

\footnotetext{
* Corresponding author.

** Corresponding author.

E-mail addresses: pesp@uaem.mx (P. Sánchez-Portillo), vbarba@uaem.mx (V. Barba).
} 
the absorption spectra are affected by the respective increase or decrease in electron density on the chromophore moiety [25]. Furthermore, the color changes are more successfully observed when the interacting species includes electrostatic charges (i. e., cation-anion) than for neutral molecules [26].

The search of metal sensors is an important topic today [27-35], especially iron and copper metals have significant relevance because they are involved in several biological and environmental processes [36, 37]. Iron is one of the most abundant essential transition metal ion in human body, acting as cofactor for many proteins in a wide range of biochemical reactions such as electron transport and the enzyme oxidoreductase [38]. On the other hand, copper is an essential metal found as traces in all living organisms, it helps to provide the energy needed for the biochemical processes of heme oxygenase in blood [39].

The synthesis of ligands that selectively coordinates with metals of biological importance is still under research attention. To the best of our knowledge, until now no boronic ester coupled to the imine-pyridine fragment has been used as metal sensors. Previously, we reported the one-step synthesis of imine-boronic esters functionalized with pyridine moieties, which were found to form 2D structural arrangements by mean of intermolecular interactions $[40,41]$. In the present work, the synthesis of imine-pyridine-boronic ester derivatives was carried out, the compounds include pyridyl moieties in ortho position within the Schiff base, the structural 1,4 N-N' disposition allows the metal centers to form five member chelates. Complexation was monitored by naked-eye, UV-Vis and Fluorescence techniques.

\section{Experimental}

\subsection{Materials and measurements}

All reagents and solvents were acquired from commercial suppliers and used without further purification. The ${ }^{1} \mathrm{H},{ }^{13} \mathrm{C}$ and ${ }^{11} \mathrm{~B}$ spectra were recorded at room temperature using a Varian VXR $400 \mathrm{MHz}$ spectrometers and $\mathrm{CDCl}_{3}$ as solvent. TMS (internal, ${ }^{1} \mathrm{H}, \delta=0.00 \mathrm{ppm},{ }^{13} \mathrm{C}, \delta=0.0$ $\mathrm{ppm}$ ) and $\mathrm{BF}_{3} \cdot \mathrm{Et}_{2} \mathrm{O}$ (external, ${ }^{11} \mathrm{~B}, \delta=0.0 \mathrm{ppm}$ ) were used as standard references. Mass spectra were obtained with Jeol JMS 700 equipment. Melting points were determined with a Büchi B-540 digital apparatus. The absorption and fluorescence spectra were recorded in a Thermo Scientific Genesys 10S UV-Vis and a Varian CaryEclipse in $2.00 \mathrm{~mL}$ quartz cells with $1 \mathrm{~cm}$ path lengh using methanol as solvent. All data treatment were analyzed with Origin software [42].

\subsection{General synthesis of compounds 1 a - 1c}

The synthesis of the compounds was carried out using one-step reactions. Starting materials were added in equimolar ratio (following the order carboxylpyridine, boronic acid and aminodiol), to a flask containing the solvent mixture of methanol $(25 \mathrm{~mL}) /$ toluene $(5 \mathrm{~mL})$. The mixture was heated under reflux conditions for $24 \mathrm{~h}$ using a Dean Stark trap to remove the condensation water. After work up, the solvent was reduced to $<10 \mathrm{~mL}$ to induce the precipitation of compounds, the obtained solids were washed with $10 \mathrm{~mL}$ of diethyl ether.

\subsubsection{Synthesis of compound 1a}

Obtained from 4-(trifluoromethyl)phenylboronic acid (399.7 mg, $2.102 \mathrm{mmol}$ ), 2-amino-1,3-propanediol (193.2 g, $2.102 \mathrm{mmol}$ ) and 2pyridinecarboxaldehyde $(200 \mu \mathrm{L}, 2.102 \mathrm{mmol})$. 34\% yield of a paleyellow solid. M.P. $=145-148{ }^{\circ} \mathrm{C}$. IR (ATR) $v: 1640(\mathrm{C}=\mathrm{N}, w), 1309$ (m), $1251(\mathrm{~m}) 1103(\mathrm{~s}), 648(\mathrm{~s}) .{ }^{1} \mathrm{H}$ NMR (400 MHz, $\left.\mathrm{CDCl}_{3}\right) \delta=8.64$ (dd, $\left.J_{\text {ortho }}=4.9 \mathrm{~Hz}, J_{\text {meta }}=1.6 \mathrm{~Hz}, 1 \mathrm{H}, \mathrm{H}-8\right), 8.53(\mathrm{~s}, 1 \mathrm{H}, \mathrm{H}-3), 7.97$ (dd, $\left.J_{\text {ortho }}=7.8 \mathrm{~Hz}, J_{\text {meta }}=1.6 \mathrm{~Hz}, 1 \mathrm{H}, \mathrm{H}-5\right), 7.90(d, J=7.8 \mathrm{~Hz}, 2 \mathrm{H}, \mathrm{H}-10)$, $7.72\left(d d d, J_{\text {ortho }}=7.8 \mathrm{~Hz}, J_{\text {ortho }}=7.8 \mathrm{~Hz}, J_{\text {meta }}=1.6 \mathrm{~Hz}, 1 \mathrm{H}, \mathrm{H}-6\right), 7.58$ $(d, J=7.8 \mathrm{~Hz}, 2 \mathrm{H}, \mathrm{H}-11), 7.33$ (ddd, $J_{\text {ortho }}=7.8 \mathrm{~Hz}, J_{\text {ortho }}=4.9 \mathrm{~Hz}, J_{\text {meta }}$ $=1.6 \mathrm{~Hz}, 1 \mathrm{H}, \mathrm{H}-7), 4.24(d, J=6 \mathrm{~Hz}, 4 \mathrm{H}, \mathrm{H}-1), 3.93(q, J=6.2 \mathrm{~Hz}, 1 \mathrm{H}$, $\mathrm{H}-2$ ), ${ }^{13} \mathrm{C}$ NMR (126 MHz, $\mathrm{CDCl}_{3}$ ) $\delta=164.5$ (C-3), 154.0 (C-4), 149.8 (C-
Table 1

Selected crystallographic data of compounds 1a-1c.

\begin{tabular}{|c|c|c|c|}
\hline Identification code & $1 \mathrm{a}$ & $1 b$ & $1 \mathrm{c}$ \\
\hline Empirical formula & $\mathrm{C}_{16} \mathrm{H}_{14} \mathrm{BF}_{3} \mathrm{~N}_{2} \mathrm{O}_{2}$ & $\mathrm{C}_{17} \mathrm{H}_{16} \mathrm{BF}_{3} \mathrm{~N}_{2} \mathrm{O}_{2}$ & $\mathrm{C}_{16} \mathrm{H}_{16} \mathrm{BBrN}_{2} \mathrm{O}_{2}$ \\
\hline Formula weight & 334.10 & 348.13 & 359.03 \\
\hline \multirow[t]{2}{*}{ Crystal size $\left(\mathrm{mm}^{3}\right)$} & $0.22 \times 0.12 x$ & $0.28 \times 0.16 x$ & $0.26 \times 0.14 X$ \\
\hline & 0.08 & 0.12 & 0.12 \\
\hline Crystal system & Triclinic & Monoclinic & Monoclinic \\
\hline Space group & P-1 & $P 2_{1} / c$ & $P 2_{1} / c$ \\
\hline Temp. (K) & 100 & 100 & 293 \\
\hline \multicolumn{4}{|l|}{$\begin{array}{l}\text { Unit cell } \\
\text { dimensions }\end{array}$} \\
\hline a $[\AA ̊]$ & $8.9366(8)$ & $6.6530(3)$ & $6.63819(13)$ \\
\hline b [Å] & $9.4794(8)$ & $9.8202(5)$ & $9.7342(2)$ \\
\hline c [Å] & $9.7470(7)$ & $24.317(2)$ & $24.1639(5)$ \\
\hline$\alpha\left[{ }^{\circ}\right]$ & $73.290(7)$ & 90 & 90 \\
\hline$\beta\left[{ }^{\circ}\right]$ & $87.498(6)$ & $93.859(5)$ & 92.8341 (17) \\
\hline$\gamma\left[{ }^{\circ}\right]$ & $73.545(8)$ & 90 & 90 \\
\hline Volume $\left[\AA^{3}\right]$ & $757.81(11)$ & $1585.16(17)$ & $1559.51(5)$ \\
\hline $\mathrm{Z}$ & 2 & 4 & 4 \\
\hline$\rho_{\text {calcd }}\left[\mathrm{g} / \mathrm{cm}^{3}\right]$ & 1.464 & 1.459 & 1.525 \\
\hline$\mu\left[\mathrm{mm}^{-1}\right]$ & 1.039 & 0.119 & 3.654 \\
\hline Collected refl. & 4728 & 7408 & 5184 \\
\hline $\begin{array}{l}\text { Independent refl } \\
\qquad\left(\mathbf{R}_{\text {int }}\right)\end{array}$ & 2912 & 3603 & 3028 \\
\hline $\begin{array}{l}\text { Observed refl. }[\mathrm{I}> \\
2 \sigma \text { (I)] }\end{array}$ & 2578 & 3024 & 2743 \\
\hline Parameters & 344 & 720 & 724 \\
\hline $\begin{array}{l}\mathrm{R}[\mathrm{I}>2 \sigma(\mathrm{I})] \mathrm{R}_{1} / \\
\quad \mathrm{w} R_{2}\end{array}$ & $0.0424 / 0.1174$ & $0.0641 / 0.1697$ & $0.0386 / 0.1035$ \\
\hline $\mathrm{R}$ (all data) $\mathrm{R}_{1} / \mathrm{w} R_{2}$ & $0.0472 / 0.1228$ & $0.0745 / 0.1688$ & $0.0416 / 0.1069$ \\
\hline GOOF & 1.034 & 1.028 & 1.041 \\
\hline
\end{tabular}

8), 136.9 (C-6), 134.4 (C-10), 132.6 ( $q, J_{C-F}=37.8 \mathrm{~Hz}, \mathrm{C}-12$ ), 125.5 (C7), $124.4\left(q, J_{C-F}=273 \mathrm{~Hz},-\mathrm{CF}_{3}\right), 124.4\left(q, J_{C-F}=12 \mathrm{~Hz}, \mathrm{C}-11\right), 122.0$ (C-5), 66.3 (C-1), 65.1 (C-2), (B-C was not observed). ${ }^{11} \mathrm{~B}$ NMR (128 $\left.\mathrm{MHz}, \mathrm{CDCl}_{3}\right) \delta=26, h_{1 / 2}=563 \mathrm{~Hz}$. EI ${ }^{+}$-MS-HR for $\mathrm{C}_{16} \mathrm{H}_{14} \mathrm{O}_{2} \mathrm{~N}_{2} \mathrm{~F}_{3} \mathrm{~B}, m / z$ : found $334.1113 \pm 3.7$, Calc. 334.1013.

\subsubsection{Synthesis of compound $\mathbf{1 b}$}

Obtained from 4-(trifluoromethyl)phenylboronic acid $(182.7 \mathrm{mg}$, $1.05 \mathrm{mmol}$ ), 2-amino-2-methyl-1,3-propanediol (110.3 g, $1.05 \mathrm{mmol}$ ) and 2-pyridinecarboxaldehyde (100 $\mu \mathrm{L}, 1.05 \mathrm{mmol}) .44 \%$ yield of a white solid. M.P. $=153-155^{\circ} \mathrm{C}$. IR (ATR) $v: 1637(\mathrm{C}=\mathrm{N}, w), 1293(s)$, $1251(\mathrm{~m}), 1102(\mathrm{~s}), 842(\mathrm{~m}), 649(\mathrm{~s}) .{ }^{1} \mathrm{H}$ NMR $\left(400 \mathrm{MHz}, \mathrm{CDCl}_{3}\right) \delta=8.60$ ( $\left.d d, J_{\text {ortho }}=5 \mathrm{~Hz}, J_{\text {meta }}=1.6 \mathrm{~Hz}, 1 \mathrm{H}, \mathrm{H}-8\right), 8.52(s, 1 \mathrm{H}, \mathrm{H}-3), 7.98$ (dd, $\left.J_{\text {ortho }}=7.6 \mathrm{~Hz}, J_{\text {meta }}=1.6 \mathrm{~Hz}, 1 \mathrm{H}, \mathrm{H}-5\right), 7.88(d, J=7.6 \mathrm{~Hz}, 2 \mathrm{H}, \mathrm{H}-10)$, 7.68 (ddd, $\left.J_{\text {ortho }}=7.6 \mathrm{~Hz}, J_{\text {ortho }}=7.6 \mathrm{~Hz}, J_{\text {meta }}=1.6 \mathrm{~Hz}, 1 \mathrm{H}, \mathrm{H}-6\right), 7.55$ $(d, J=7.6 \mathrm{~Hz}, 2 \mathrm{H}, \mathrm{H}-11), 7.28$ (ddd, $J_{\text {ortho }}=7.6 \mathrm{~Hz}, J_{\text {ortho }}=5 \mathrm{~Hz}, J_{\text {meta }}=$ $1.6 \mathrm{~Hz}, 1 \mathrm{H}, \mathrm{H}-7), 4.32\left(A B, J_{A B}=11 \mathrm{~Hz}, 4 \mathrm{H}, \mathrm{H}-1\right), 1.31(s, 3 \mathrm{H}, \mathrm{H}-13)$. ${ }^{13} \mathrm{C}$ NMR $\left(100 \mathrm{MHz}, \mathrm{CDCl}_{3}\right) \delta=160.9$ (C-3), 153.7 (C-4), 149.9 (C-8), 137.3 ( $m$, C-6 y C-12), 134.7 (C-10, C-12), 125.4 (C-7), 124.4 ( $q, J_{C-F}=4$ $\mathrm{Hz}, \mathrm{C}-11), 124.4\left(q, J_{C-F}=268 \mathrm{~Hz},-\mathrm{CF}_{3}\right.$ ), 121.7 (C-5), $70.3(\mathrm{C}-1), 65.3$ (C-2), (B-C was not observed). ${ }^{11} \mathrm{~B}$ NMR $\left(128 \mathrm{MHz}, \mathrm{CDCl}_{3}\right) \delta=26, h_{1 / 2}$ $=460 \mathrm{~Hz}$. EI ${ }^{+}$-MS-HR for $\mathrm{C}_{17} \mathrm{H}_{16} \mathrm{O}_{2} \mathrm{~N}_{2} \mathrm{~F}_{3} \mathrm{~B}, \mathrm{~m} / z$ : found $348.1235 \pm 6.2$, Calc. 348.1280.

\subsubsection{Synthesis of compound 1c}

Obtained from 4-bromo-phenylboronic acid (210.9 mg, $1.05 \mathrm{mmol})$, 2-amino-2-methyl-1,3-propanediol (110.2 g, $1.05 \mathrm{mmol}$ ) and 2-pyridinecarboxaldehyde $(100 \mu \mathrm{L}, 1.05 \mathrm{mmol}) .83 \%$ yield of a white solid. M.P. $=201-204^{\circ} \mathrm{C} .{ }^{1} \mathrm{H}$ NMR $\left(400 \mathrm{MHz}, \mathrm{CDCl}_{3}\right) \delta=8.60$ (dd, $J_{\text {ortho }}=4.7$ $\left.\mathrm{Hz}, J_{\text {meta }}=1.2 \mathrm{~Hz}, 1 \mathrm{H}, \mathrm{H}-8\right), 8.51(s, 1 \mathrm{H}, \mathrm{H}-3), 7.96\left(d d, J_{\text {ortho }}=7.8 \mathrm{~Hz}\right.$, $\left.J_{\text {meta }}=1.2 \mathrm{~Hz}, 1 \mathrm{H}, \mathrm{H}-5\right), 7.87$ (d, $\left.J_{\text {ortho }}=7.8 \mathrm{~Hz}, 2 \mathrm{H}, \mathrm{H}-10\right), 7.69$ (ddd, $\left.J_{\text {ortho }}=7.8 \mathrm{~Hz}, J_{\text {ortho }}=7.8 \mathrm{~Hz}, J_{\text {meta }}=1.2 \mathrm{~Hz}, 1 \mathrm{H}, \mathrm{H}-6\right), 7.44\left(d, J_{\text {ortho }}=\right.$ $7.8 \mathrm{~Hz}, 2 \mathrm{H}, \mathrm{H}-11$ ), 7.29 (ddd, $J_{\text {ortho }}=7.8 \mathrm{~Hz}, J_{\text {ortho }}=4.7 \mathrm{~Hz}, J_{\text {meta }}=1.2$ $\mathrm{Hz}, 1 \mathrm{H}, \mathrm{H}-7), 4.12\left(A B, J_{A B}=10.8 \mathrm{~Hz}, 4 \mathrm{H}, \mathrm{H}-1\right), 1.30(s, 3 \mathrm{H}, \mathrm{H}-13) .{ }^{13} \mathrm{C}$ NMR (100 MHz, $\left.\mathrm{CDCl}_{3}\right) \delta=160.7$ (C-3), 154.8 (C-4), 149.6 (C-8), 136.9 (C-6), 135.9 (C-10), 131.0 (C-11), 125.9 (C-12), 125.3 (C-7), 121.5 (C5), 70.3 (C-1), 59.4 (C-2), 20.2 (C-13), (B-C was not observed). ${ }^{11} \mathrm{~B}$ NMR 
<smiles>[R]c1ccc(B(O)O)cc1</smiles><smiles></smiles>

Scheme 1. Synthetic strategy to obtain 1a-1c compounds. Numbering is for NMR assignments.

(128 MHz, $\left.\mathrm{CDCl}_{3}\right) \delta=26, h_{1 / 2}=520 \mathrm{~Hz} . \mathrm{EI}^{+}$-MS-HR for $\mathrm{C}_{16} \mathrm{H}_{16} \mathrm{O}_{2} \mathrm{~N}_{2} \mathrm{BrB}, \mathrm{m} / z$ : found $358.0493 \pm 1.3$, Calc. 358.0488 .

\subsection{X-ray measurements}

Crystal intensity data were collected at $T=100 \mathrm{~K}$ for $\mathbf{1 a}$ and $\mathbf{1 b}$, (293 K for 1c), using Cu-K $\alpha$ radiation $\lambda=1.54184 \AA$, for 1a and 1c (Mo$\mathrm{K}_{\alpha}$ radiation $\lambda=0.71073 \AA$ for $\mathbf{1 b}$ ), graphite monochromator on an Agilent Technologies SuperNova diffractometer equipped with the EOsS2 CCD area detector and an Oxford Instruments Cryogen cooler. Crystal data, data collection parameters and convergence results are listed in Table 1. The measured intensities were reduced to $F^{2}$ and corrected for absorption using spherical harmonics (CryAlisPro) [43]. Intensities were corrected for Lorentz and polarization effects. Structure solution, refinement, and data output were performed with the OLEX2 program package [44] using SHELXL-2014 [45] for the refinement. Non-hydrogen atoms were refined anisotropically. All hydrogen atoms were placed in geometrically calculated positions using the riding model. Intermolecular distances were analyzed with MERCURY [46]. The Hirshfeld surfaces were calculated by CrystalExplorer software [47].

\subsection{Computational studies}

The geometries of ligands 1a (transoid) and $\mathbf{1 b}$ (bent "L"), as well as the complexes $\left[\mathrm{Fe}(\mathbf{1 a})_{3}\right]^{2+},\left[\mathrm{Fe}(\mathbf{1} \mathbf{b})(\mathrm{MeOH})_{4}\right]^{2+}$ and $\left[\mathrm{Fe}(\mathbf{1 b})_{3}\right]^{2+}$ were fully optimized using the Gaussian-09 program package [48] within the framework of the Density Functional Theory (DFT). The computed geometries of the five species are provided as supplementary materials. In any case, the computations were performed in the presence of methanol as the solvent, which was modelized by the Polarizable Continuum Model (SCRF $=$ PCM method) [49]. The combination of the widely used B3LYP hybrid functional [50,51], with the double- $\zeta$ basis set $6-31 \mathrm{G}^{*}$ [52], was employed. The UV-Vis spectra were computed by Time-Dependent Density Functional Theory (TD-DFT), using the geometries of the optimized cations. In order to select the suitable method for these computations, several functional were tested (B3LYP, B3PW91, CAM-B3LYP, and PBE0). Finally, the B3PW91 [50] was chosen for its better accuracy to reproduce the experimental transition energies $(<0.5$ $\mathrm{eV}$ ). The spectra were drawn by Gabedit software [53].

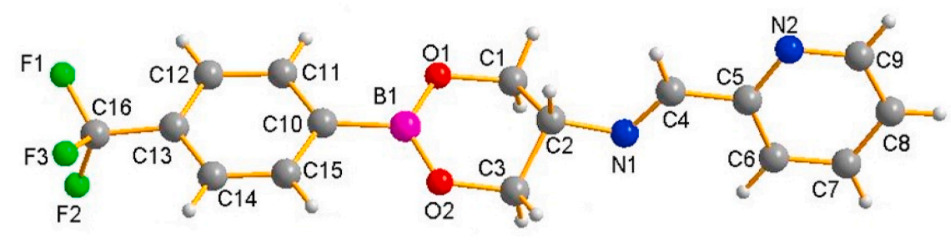

1a

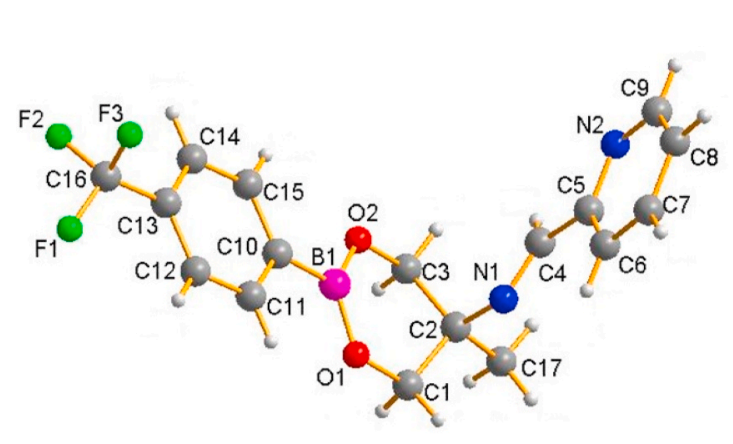

1b

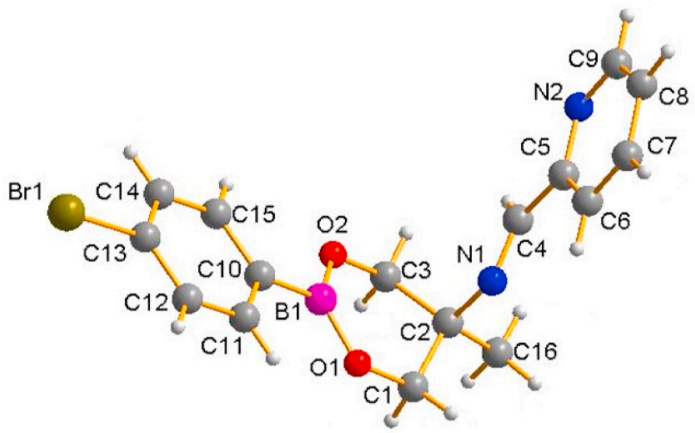

1c

Fig. 1. X-ray crystal structures of compounds 1a-1c. 
Table 2

Selected bond distances $(\AA)$, angles $\left(^{\circ}\right)$ and torsion angles $\left(^{\circ}\right)$ of compounds 1a$1 c$.

\begin{tabular}{llll}
\hline & $1 \mathrm{a}$ & $1 \mathrm{~b}$ & $1 \mathrm{c}$ \\
\hline B1-O1 & $1.358(2)$ & $1.362(3)$ & $1.362(3)$ \\
B1-02 & $1.358(2)$ & $1.361(3)$ & $1.357(3)$ \\
B1-C10 & $1.571(2)$ & $1.578(3)$ & $1.568(3)$ \\
N1-C2 & $1.4639(18)$ & $1.487(3)$ & $1.486(2)$ \\
N1-C4 & $1.267(2)$ & $1.264(3)$ & $1.246(3)$ \\
O1-B1-C10 & $118.16(13)$ & $118.04(19)$ & $118.37(17)$ \\
O1-B1-O2 & $123.72(14)$ & $124.20(2)$ & $123.7(2)$ \\
O2-B1-C10 & $118.02(13)$ & $117.68(19)$ & $117.92(17)$ \\
C2-N1-C4 & $116.34(12)$ & $117.99(18)$ & $119.15(17)$ \\
C11-C10-B1-O1 & $5.9(2)$ & $2.6(3)$ & $1.9(3)$ \\
C10-B1-O1-C1 & $-173.1(1)$ & $179.0(2)$ & $179.3(2)$ \\
B1-O1-C1-C2 & $-29.6(2)$ & $24.8(2)$ & $26.1(2)$ \\
O1-C1-C2-N1 & $172.2(1)$ & $69.2(2)$ & $69.5(2)$ \\
C1-C2-N1-C4 & $100.6(2)$ & $-169.1(2)$ & $170.0(2)$ \\
C2-N1-C4-C5 & $178.3(1)$ & $179.6(2)$ & $-179.3(2)$ \\
N1-C4-C5-C6 & $-5.1(2)$ & $8.7(3)$ & $7.4(3)$ \\
\hline
\end{tabular}

\section{Results and discussion}

\subsection{Syntheses and characterization}

The present work describes one-step reactions using 4-substituted arylboronic acids (4-(trifluoromethyl)phenylboronic acid for 1a and 1b, 4-bromophenylboronic acid for 1c), 2-amino-2-methyl-1,3-propanodiol for $\mathbf{1 b}$ and 1c (2-amino-1,3-propanediol for 1a), and 2-pyridine carboxaldehyde to obtain the three pyridine-imine boronic esters 1a1c (Scheme 1). Presence of the $\mathrm{CF}_{3}$ and $\mathrm{Br}$ as 4-substituent at arylboronic acids, were introduced in order to modify the acid character of the boron atom on the ester formed, and to get the formation of more structured complexes by self-assembly using $\mathrm{N} \rightarrow \mathrm{B}$ coordination bonds. Compounds $\mathbf{1 b}$ and $\mathbf{1 c}$ were isolated as white solids (pale yellow for $\mathbf{1 a}$ ) which were soluble in organic solvents. Spectroscopy characterization was done using IR spectroscopy, mass spectrometry, ${ }^{1} \mathrm{H},{ }^{13} \mathrm{C}$ and ${ }^{11} \mathrm{~B}$ NMR spectroscopy and X-ray diffraction analysis.

First evidence for the formation of compounds 1a-1c was obtained from IR spectra, the $\mathrm{C}=\mathrm{N}$ imine band was observed around $1650 \mathrm{~cm}^{-1}$, being characteristic for these type of compounds [1,41]. Using high resolution mass spectrometry (HR-EI ${ }^{+}$technique), the $m / z$ peak corresponding to the molecular ion $[\mathrm{M}]^{+}$was observed for all three compounds showing good agreement between the isotopic distribution calculated and experimental data [54]. The ${ }^{1} \mathrm{H}$ NMR spectra showed the signal for the imine hydrogen shifted at $\delta=8.53,8.52$ and $8.51 \mathrm{ppm}$ for $\mathbf{1 a}, \mathbf{1} \mathbf{b}$ and $\mathbf{1 c}$, respectively, being in the reported range for imines [55, 56]. Hydrogen signals corresponding to aryl moieties were observed at low field $\delta=7.60-8.60 \mathrm{ppm}$. Signals for hydrogens of methylene groups $\left(\mathrm{CH}_{2}\right)$ were observed as $A B$ system at $\delta=4.32$ and $4.12 \mathrm{ppm}$, for compounds $1 \mathbf{b}$ and $1 \mathbf{c}$ respectively. For $1 \mathbf{a}$, the $\mathrm{CH}_{2}$ group was observed as doublet at $\delta=4.24 \mathrm{ppm}$. The ${ }^{13} \mathrm{C}$ NMR spectra showed signals corresponding to imine groups at $\delta=164.6,160.9$ and $160.7 \mathrm{ppm}$ for 1a-1c, respectively. The ${ }^{11} \mathrm{~B}$ NMR spectra showed signals around $\delta=26 \mathrm{ppm}$, in agreement with the formation of tri-substituted boronic esters [57].

\subsection{X-ray crystal structures}

Suitable crystals for X-ray diffraction analysis were obtained from slow evaporation of the mother liquor for all three compounds. Fig. 1 shows the molecular structures for the three compounds (1a-1c). Table 1 summarizes the selected crystallographic data and Table 2 shows selected bond distances, angles and torsion angles. The X-ray diffraction confirms the formation of boronic esters and imine bonds, all compounds have a tricoordinated boron atom having angles close to $120^{\circ}$, corresponding to a distorted trigonal planar geometry. Results indicated that, despite the presence of Lewis acid moieties (boronic ester) and Lewis bases (pyridine and imine moieties), the $\mathrm{N} \rightarrow \mathrm{B}$ dative bond was not observed, being attributed to electronic and steric effects as already reported [40]. The B-O lengths are in the range of 1.358 and $1.362 \AA$, which are less than the sum of covalent radius because of the $\pi$ retro-donating effect. It is interesting to remark that the whole conformation of compounds depends on the substituent at the $\mathrm{C} 2$ of the 6-membered heterocycle, thus when a hydrogen atom is present (1a) the compound acquires a linear conformation, whereas when it is replaced by a $\mathrm{CH}_{3}$ group, a bent " $\mathrm{L}$ " conformation is observed. This effect has been observed in analogous compounds and mainly attributed to steric effects [41].

An aspect that immediately strikes upon comparison of the solidstate X-ray structure of $\mathbf{1 a}$ and $\mathbf{1 b}$ is the observation of so different molecular structure for entities, which differ by a methyl group only. This rather surprising difference rises the issue of its origin, either intramolecular or intermolecular, by virtue of packing effect. At first, it seems that the magnitude of intermolecular interactions is similar in 1a and $1 \mathrm{~b}$ with densities calculated of 1.464 and 1.459, respectively. Additionally, the number of intermolecular short contacts is equal to 19 for $\mathbf{1 a}$, and 16 for $\mathbf{1 b}$, which suggests no significant difference in the strength of the interactions network for both species. At the molecular level, the Gibbs free energies (G) were calculated by DFT for the two species in the linear and in the bent " $\mathrm{L}$ " conformations [48]. In the case of 1a, the linear form appears to be the more stable with the bent conformation located at $3.55 \mathrm{kcal} / \mathrm{mol}$ above the ground state conformation. It is worth pointing out that the stable conformation corresponds to the transoid structure depicted in Scheme 2, which is indeed
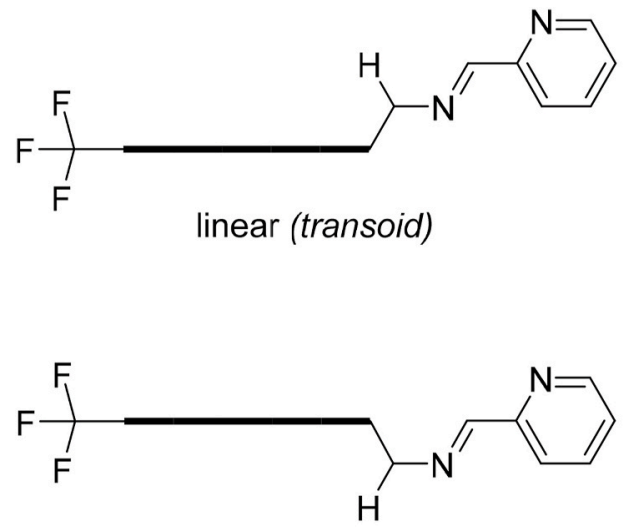

linear (cisoid)

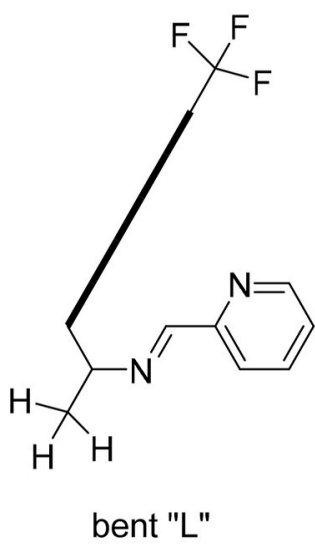

Scheme 2. Transoid and cisoid conformations for 1a, and the bent "L" conformation for $\mathbf{1 b}$. 
Table 3

Main non-covalent interactions present in 1a-1c.

\begin{tabular}{|c|c|c|c|c|c|}
\hline Compound & Interaction & $\begin{array}{l}\text { Distance } \\
\text { (§̊) D-X ... } \\
\text { A }\end{array}$ & $\begin{array}{l}\text { Distance } \\
\text { (§) } \mathrm{X} \ldots \mathrm{A}\end{array}$ & $\begin{array}{l}\text { Angle } \\
\left(^{\circ}\right) \mathrm{D}-\mathrm{X} \\
\ldots \mathrm{A}\end{array}$ & $\begin{array}{l}\text { Symmetry } \\
\text { operation }\end{array}$ \\
\hline \multirow[t]{6}{*}{$1 \mathrm{a}$} & $\begin{array}{l}\text { C (3)-H } \\
(3 \mathrm{~B}) \cdots \mathrm{F}(2)\end{array}$ & 3.287 & 2.550 & 132.7 & $\mathrm{X},-1+\mathrm{y}, \mathrm{z}$ \\
\hline & $\begin{array}{l}\mathrm{C}(8)-\mathrm{H}(8) \\
\ldots \mathrm{F}(2)\end{array}$ & 3.388 & 2.521 & 155.1 & $\begin{array}{l}\mathrm{X}, 2+\mathrm{y}, 1+ \\
\mathrm{z}\end{array}$ \\
\hline & $\begin{array}{l}\mathrm{C}(12)-\mathrm{H} \\
(12) \ldots \mathrm{N} \\
(2)\end{array}$ & 3.539 & 2.662 & 157.5 & -x,3-y,-z \\
\hline & $\begin{array}{l}\mathrm{C}(4)-\mathrm{H}(4) \\
\ldots \mathrm{N}(2)\end{array}$ & 3.587 & 2.667 & 170.4 & $-x, 4-y,-z$ \\
\hline & $\begin{array}{l}\mathrm{C}(1)-\mathrm{H}(1 \mathrm{~A}) \\
\ldots \mathrm{O}(1)\end{array}$ & 3.440 & 2.580 & 147.8 & -x,3-y,-z \\
\hline & $\begin{array}{l}\mathrm{C}(7)-\mathrm{H}(7) \\
\ldots \pi\end{array}$ & 3.502 & 2.643 & 153.9 & 1-x,3-y,-z \\
\hline \multirow[t]{4}{*}{$1 b$} & $\begin{array}{l}\mathrm{C}(3)-\mathrm{H}(3 \mathrm{~A}) \\
\ldots \mathrm{F}(1)\end{array}$ & 3.068 & 2.609 & 109.2 & $\begin{array}{l}-x,-1 / 2+ \\
y, 1 / 2-z\end{array}$ \\
\hline & $\begin{array}{l}C(12)-H \\
(12) \ldots F(3)\end{array}$ & 3.338 & 2.628 & 133.6 & $\begin{array}{l}-1-x,-1 / 2+ \\
y, 1 / 2-z\end{array}$ \\
\hline & $\begin{array}{l}\mathrm{C}(3)-\mathrm{H}(3 \mathrm{~A}) \\
\ldots \mathrm{N}(2)\end{array}$ & 3.586 & 2.743 & 145.7 & 1-x,1-y,1-z \\
\hline & $\begin{array}{l}\text { C (16)-F3 } \\
\text { (3) ... B (1) }\end{array}$ & 4.197 & 3.288 & 126.0 & $-1+\mathrm{x}, \mathrm{y}, \mathrm{z}$ \\
\hline \multirow[t]{2}{*}{$1 \mathrm{c}$} & $\begin{array}{l}\text { C (15)-H } \\
(15) \ldots \pi\end{array}$ & 4.293 & 3.474 & 148.3 & $\begin{array}{l}3-x, 1 / 2+ \\
y, 1.5-z\end{array}$ \\
\hline & $\begin{array}{l}\mathrm{C}(7)-\mathrm{H}(7) \\
\ldots \mathrm{O}(1)\end{array}$ & 3.467 & 2.611 & 153.2 & $3-x,-y, 2-z$ \\
\hline
\end{tabular}

that observed in the solid state. By contrast, the bent "L" conformation appears more stable in the case of $\mathbf{1 b}$, with the linear transoid structure located at $1.51 \mathrm{kcal} / \mathrm{mol}$ above the ground state geometry. Altogether, these computations fully agree with the observed geometries and leads to the conclusion that the solid-state conformation in both systems are mainly governed by intramolecular effects.

\subsection{Non-covalent interactions}

As mentioned above, $\mathrm{N} \rightarrow \mathrm{B}$ dative bond formation was constrain by electronic and steric effects, in addition, the boronic ester is part of a sixmembered heterocycle, wherein the boron atom acidity is diminished in comparison with the analogous five-membered heterocycles where the $\mathrm{N} \rightarrow \mathrm{B}$ interaction is favored [6]. Nevertheless, the imine-boronic esters 1a-1c contain several functional groups which can form non-covalent intermolecular interactions such as hydrogen bonding, $\pi$ interactions and halogen interactions. The non-covalent interactions observed for all three compounds are summarized in Table 3. Mainly, hydrogen bonding
$\mathrm{C}-\mathrm{H} \cdots \mathrm{O}(2.580,2.611 \AA), \mathrm{C}-\mathrm{H} \cdots \mathrm{N}(2.662,2.667$ and $2.743 \AA$ 丹 ) and $\mathrm{C}-\mathrm{H} \cdots \mathrm{F}(2.521,2.550$ and $2.609 \AA)$ are the most common non-covalent interactions observed (Fig. S1). Additionally, $\mathrm{C}-\mathrm{H} \ldots \pi(2.643$ and 3.474

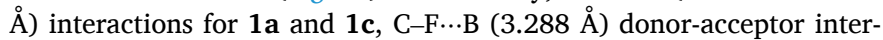
action for $\mathbf{1 b}$ and, C-H..F (3.068-3.338 $\AA$ ) interactions for $\mathbf{1 a}$ and $\mathbf{1 b}$ were observed, distances are in the range already reported [58-60]. The $\mathrm{C}-\mathrm{H} \cdots \mathrm{F}$ interactions allow the formation of $2 \mathrm{D}$ arrangements as depicted at Fig. 2.

Hirshfeld surface analysis [61-63] was carried out to obtain additional information on the nature of intermolecular interactions. The red areas on the surface mapped with $\mathrm{d}_{\text {norm }}$ function were located on electronegative atoms which are responsible of strong hydrogen bonds. Fig. 3 shows the Hirshfeld surface for compound 1a (for compounds $\mathbf{1 b}$ and 1c see supplementary information, Figs. S2 and S3 respectively), showing the red areas located at oxygen atoms (boronic ester) and nitrogen atoms (pyridine groups) which participate in $\mathrm{C}-\mathrm{H} \cdots \mathrm{O}$ and $\mathrm{CH} \ldots$ $\cdot \mathrm{N}$ hydrogen bonds. When 2D fingerprint plots are partitioned [50], the $\mathrm{H} / \mathrm{H}$ interaction are seen to be the most dominant interactions in all three cases, followed by F-H contacts (for compounds $\mathbf{1 a}$ and $\mathbf{1 b}$ ) which are responsible of the molecular packing, in contrast, for compound 1c the second dominant interaction is the $\mathrm{C}-\mathrm{H} \ldots \pi$. Table 4 summarizes the relative contribution of interactions (\%) for compounds 1a-1c.

\subsection{Cation sensing studies}

The imine-pyridine [22,64] or imine-phenol [65] moieties have been reported to act as chromophores for a variety of compounds since their photophysical properties can be modify by mean of metal-ligand interaction. Compounds 1a-1c showed an absorption band at $290 \mathrm{~nm}$ (Fig. S4). Sensitivity tests were carried out for compound 1a towards some metal cations from the first-row transition metals $\left(\mathrm{M}^{2+}=\mathrm{Fe}^{2+}\right.$, $\mathrm{Co}^{2+}, \mathrm{Ni}^{2+}, \mathrm{Cd}^{2+}, \mathrm{Cu}^{2+}$ and $\left.\mathrm{Zn}^{2+}\right)$. Visible color changes were observed when methanol solutions of $\mathrm{M}^{2+}\left(1 \times 10^{-3} \mathrm{M}\right)$ were added to $1 \mathrm{a}$ methanol solution in a 1:1 ratio (metal:ligand). Although most of the sensory analysis are carried out in aqueous solution because of the environmental, industrial and medical applications, many related reports use methanol as medium to determinate these properties $[15,16$, 66]. Herein, boronic esters decompose gradually in water solution and thus, methanol was the selected solvent for the analysis. Fig. 4 shows the colorimetric behavior observed for $1 \mathrm{a}$ after the addition of $\mathrm{M}^{2+}$ solutions. The most representative change was noticed using $\mathrm{Fe}^{2+}$, the solution turns purple from an initial colorless solution from free 1a. By addition of $\mathrm{Co}^{2+}$ and $\mathrm{Cu}^{2+}$ methanol solutions, the 1a solution turns orange and green, respectively. Color changes variations were also monitored by UV-Vis titration experiments, it was observed that the
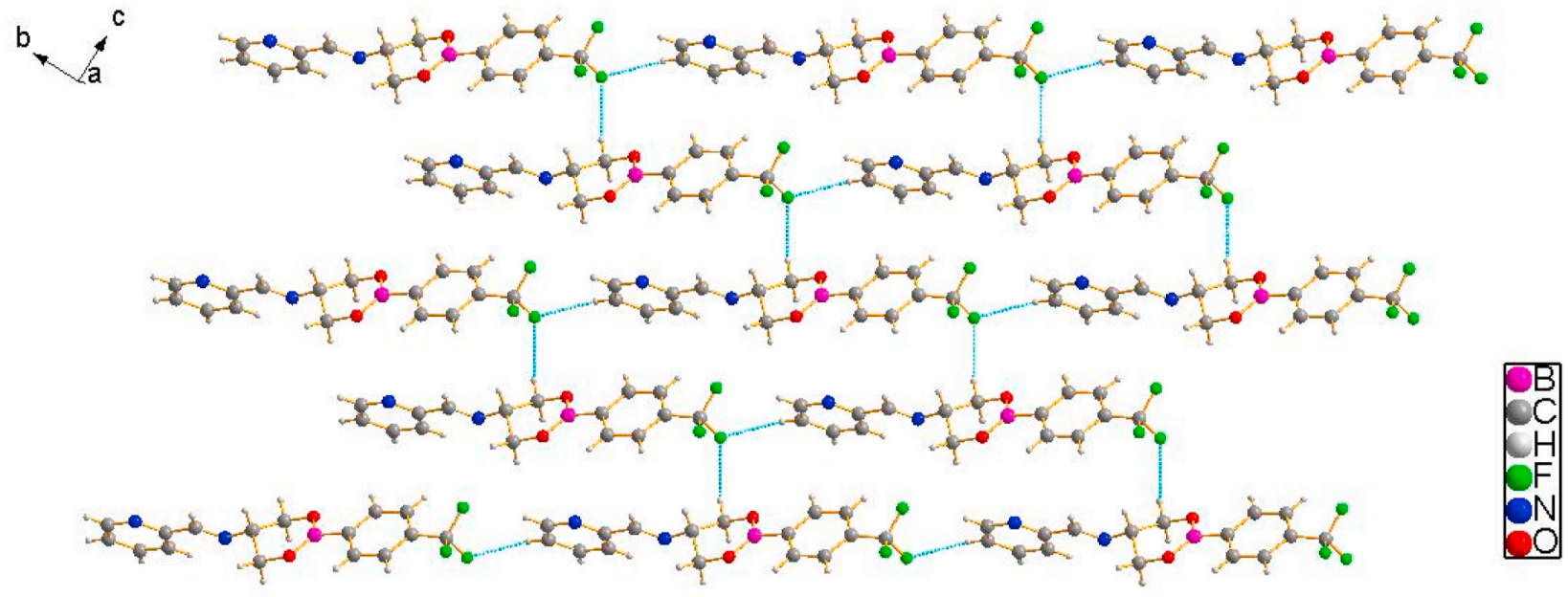

Fig. 2. 2D supramolecular polymer formed by $\mathrm{C}-\mathrm{H} \cdots \mathrm{F}$ interactions of $\mathbf{1 a}$. 


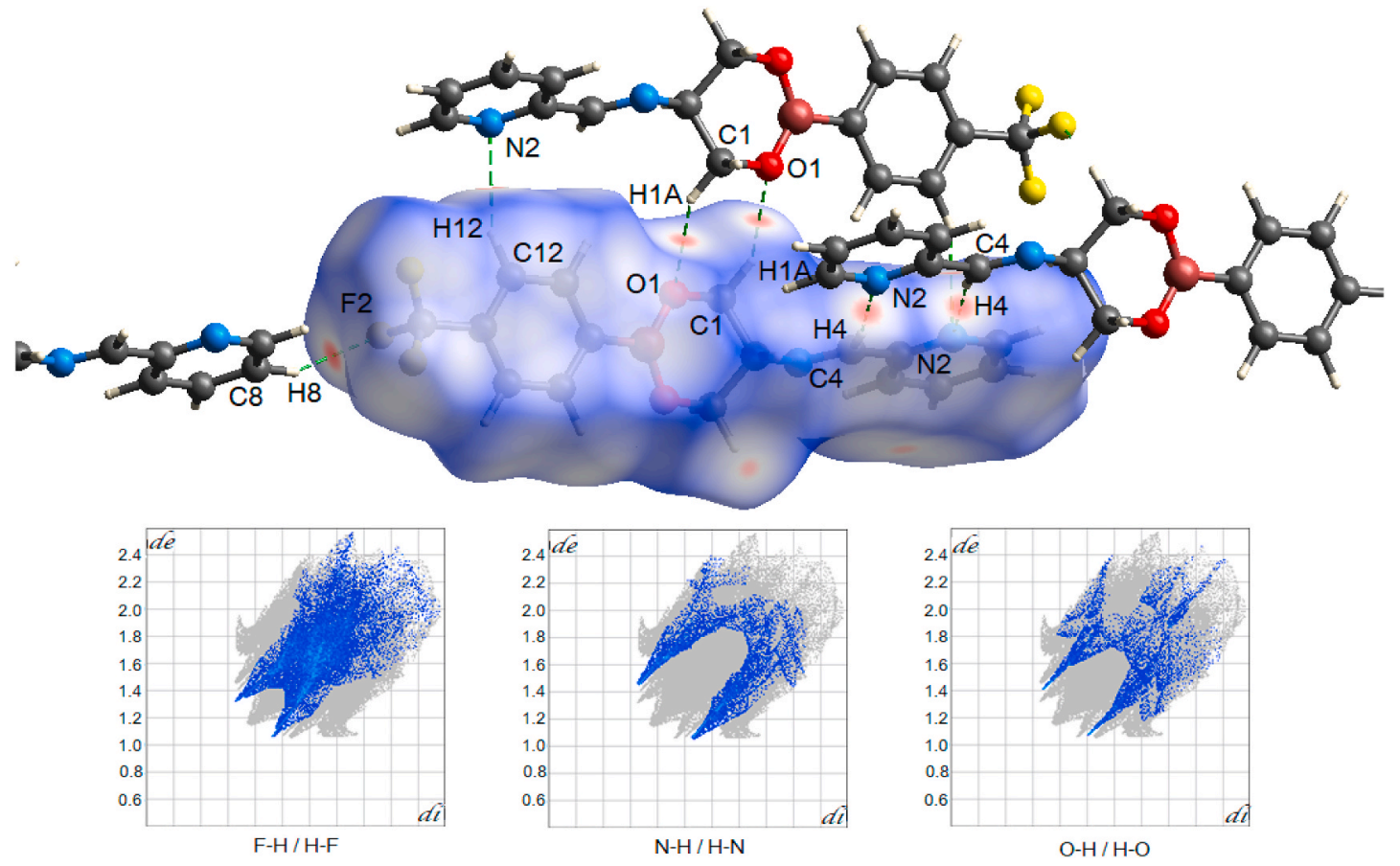

Fig. 3. Hirshfeld surface of compound 1a (up) and most representative finger prints (down).

Table 4

Relative contribution of interactions (\%) for compounds 1a-1c.

\begin{tabular}{llll}
\hline & \multicolumn{2}{l}{ Compound } & \\
\cline { 2 - 4 } & $1 \mathrm{a}$ & $1 \mathrm{~b}$ & $1 \mathrm{c}$ \\
\hline C-H/H-C (\%) & 19.4 & 16.5 & 11.8 \\
H-H (\%) & 31.0 & 37.7 & 44.6 \\
H-X/X-H (\%) & 22.4 & 18.7 & 9.9 \\
H-N/N-H (\%) & 8.6 & 6.4 & 6.7 \\
H-O/O-H (\%) & 6.2 & 7.3 & 8.1 \\
\hline
\end{tabular}

$\mathrm{X}=\mathrm{F}$ for $\mathbf{1} \mathrm{a}$ and $\mathbf{1 b}, \mathrm{Br}$ for $\mathbf{1 c}$.

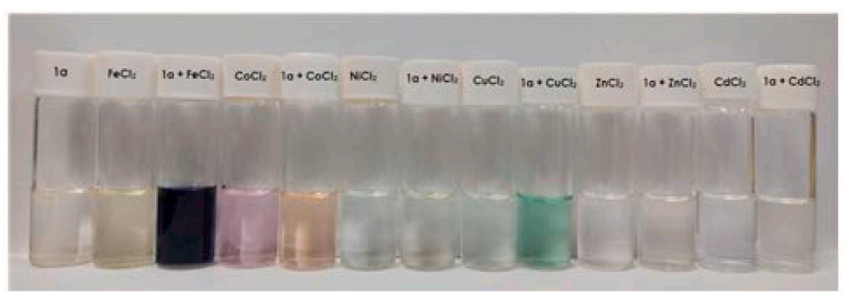

Fig. 4. Colorimetric behavior of compound 1a towards the addition of metal ions in methanol solutions.

spectrum of 1a shows increasing intensity of the band at $290 \mathrm{~nm}$ and the appearance of new bands at higher wavelengths when $\mathrm{Fe}^{2+}, \mathrm{Co}^{2+}$ and $\mathrm{Cu}^{2+}$ methanol solutions were gradually added (Fig. 5). For instance, $\mathrm{UV}-\mathrm{Vis}$ spectrum for the solution mixture of $1 \mathrm{a}-\mathrm{Fe}^{2+}$ showed two new bands at 360 and $566 \mathrm{~nm}$ which are attributed to ligand-metal charge transfer in addition to $d-d$ transitions respectively. Additionally, the absorption bands are maintained when the anion changes (i.e. $\mathrm{SO}_{4}^{2-}$ ), which suggests that the contranion does not affect the formation of the complex (Fig. S5). Similar behavior was observed for the absorption spectra of $\mathrm{Co}^{2+}$ and $\mathrm{Cu}^{2+}$ solutions, nonetheless lower intensity bands at 360 and $462 \mathrm{~nm}$ (respectively) were obtained.

The association constant $\left(K_{a}\right)$ of $1 \mathrm{a}$ with $\mathrm{Fe}^{2+}, \mathrm{Co}^{2+}$ and $\mathrm{Cu}^{2+}$ were determined during titration experiments by the following equation [67]:

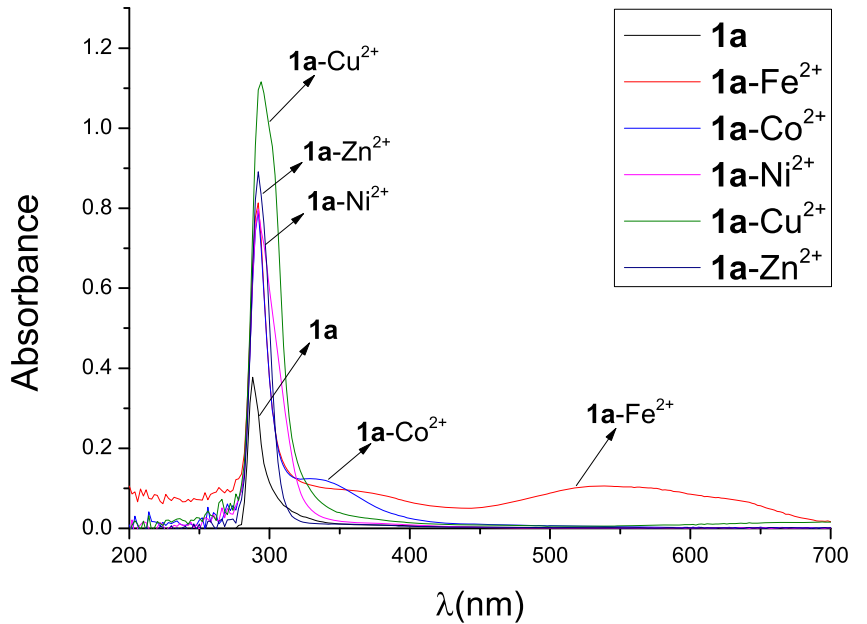

Fig. 5. UV-Vis spectral changes of $1 \mathrm{a}\left(1 \times 10^{-3} \mathrm{M}\right)$ in methanol upon the addition of equimolar concentration of different metal ion solutions (1:1 (v/ $\mathrm{v}), \mathrm{ml})$.

$$
K_{a}=\frac{A-A_{0}}{\left(A_{\max }-A_{0}\right)\left[M^{2+}\right]}
$$

where $A$ and $A_{0}$ represent the absorbance of $1 \mathrm{a}$ (at 566, 360 and $290 \mathrm{~nm}$ for $\mathrm{Fe}^{2+}, \mathrm{Co}^{2+}$ and $\mathrm{Cu}^{2+}$ respectively) in the presence and absence of $\mathrm{M}^{2+}, A_{\max }$ is the saturated absorbance of $\mathbf{1 a}$ in the presence of excess amount of $\mathrm{M}^{2+}$, while $\left[\mathrm{M}^{2+}\right]$ is the concentration of the corresponding metal ion added. The association constant $K_{a}$ resulted to be $5.51 \times 10^{3}$ $\mathrm{M}^{-1}, 3.46 \times 10^{3} \mathrm{M}^{-1}$ and $3.75 \times 10^{3} \mathrm{M}^{-1}$ for $\mathrm{Fe}^{2+}, \mathrm{Co}^{2+} \mathrm{Cu}^{2+}$ respectively by $1: 1$ binding mode. The values show a trend of $\mathrm{Fe}^{2+}>\mathrm{Cu}^{2+}>\mathrm{Co}^{2+}$ which is congruent with the observed spectral changes depicted at Fig. 6.

Titration experiment with $\mathrm{Fe}^{2+}, \mathrm{Co}^{2+}$ and $\mathrm{Cu}^{2+}$ methanol solutions allowed also to determine the stoichiometric ratio (Fig. S6), the Job's graphs are depicted at Fig. 7a-c. Results showed that $\mathbf{1 a - F e}{ }^{2+}$ complex 

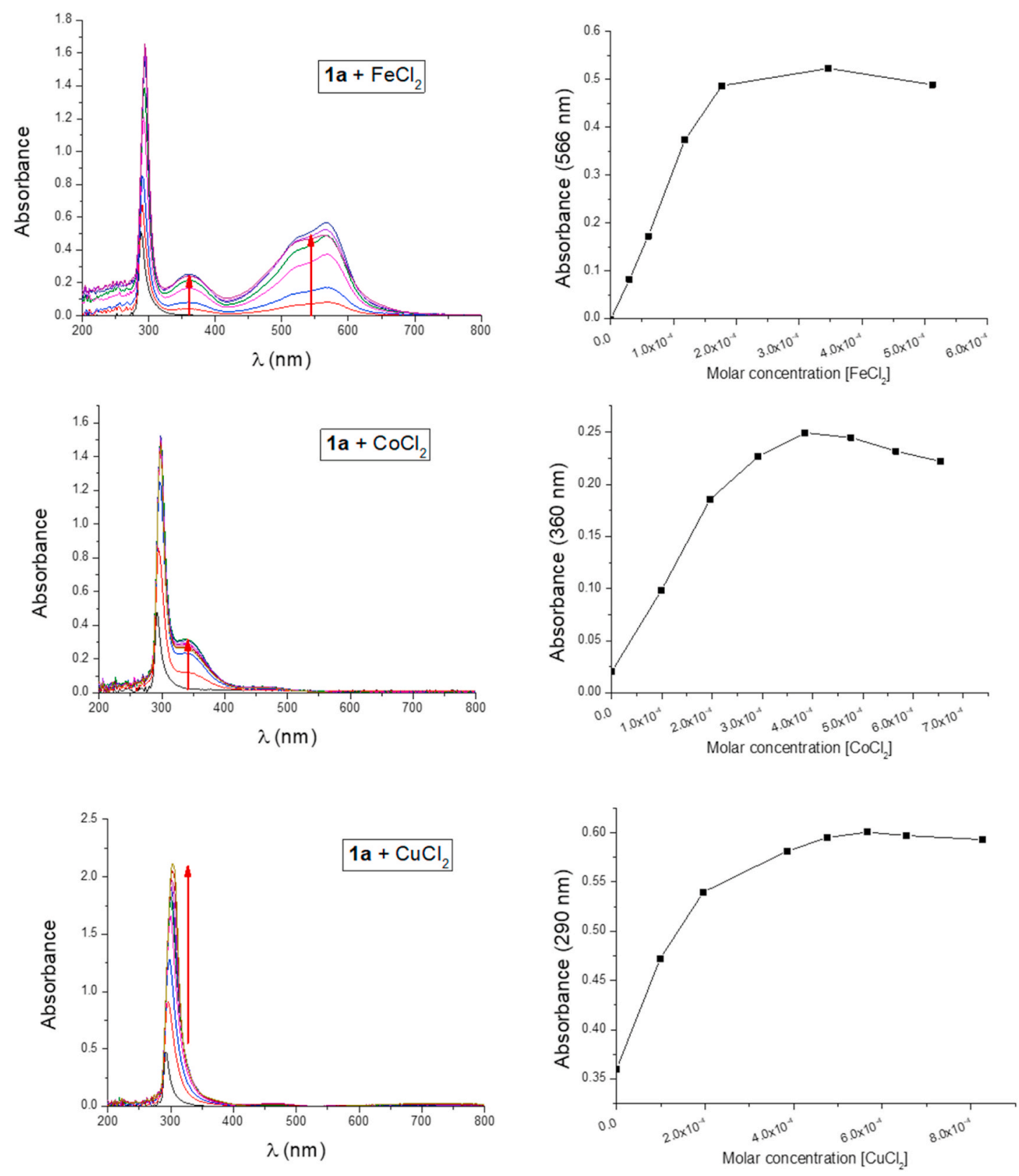

Fig. 6. Absorption spectra obtained during the titration of $1 \mathrm{a}$ with $\mathrm{Fe}^{2+}$ (top), $\mathrm{Co}^{2+}$ (middle), $\mathrm{Cu}^{2+}$ (bottom) and profile of absorbance change at 566,360 and 290 $\mathrm{nm}$ respectively. Methanol solutions $\left(1 \times 10^{-3} \mathrm{M}\right)$.

shows the maximum absorption when the fraction/molar ratio is about 0.75 , indicating a 1:3 metal:ligand stoichiometry, thus, each metal coordinates three units of 1a suggesting the hexacoordination for metals forming a $[\mathrm{Fe} \mathrm{(1a)}]^{2+}$ complex as depicted at Fig. $7 \mathrm{~d}$. In the case of 1a$\mathrm{Co}^{2+}$ and $1 \mathrm{a}-\mathrm{Cu}^{2+}$ titrations, the Job's plots show a maximum in 0.71 indicating also a stoichiometry near to $1: 3$ (spectral changes for each experiment are shown at Figs. S7-S9). Similar experiments were carried out for compounds $\mathbf{1 b}$ and $\mathbf{1 c}$, these ligands show less absorbance compared with 1a. The titrations Job's experiments showed a 1:1 stoichiometry for $\mathbf{1 b}$ while a 2:1 stoichiometry for 1c was observed (Fig. S10). The observed stoichiometric changes are attributed to the presence of $-\mathrm{CH}_{3}$ group which induce different ligand conformation and, consequently, major steric effect.

To determinate the use of 1a as selective sensor, a study of the possible interferences from competing ions was done. Experiments were carried out by adding simultaneously into methanol solutions of 1a, first a methanol solution of $\mathrm{Fe}^{2+}$ followed by methanol solutions of either $\mathrm{Co}^{2+}, \mathrm{Ni}^{2+}, \mathrm{Cu}^{2+}$ or $\mathrm{Zn}^{2+}$ (at 1 equivalent) Fig. $8 \mathrm{a}$ and $\mathrm{b}$ shows the absorbance values at 290 and $620 \mathrm{~nm}$ respectively for these combinations. Only small variations were observed at $290 \mathrm{~nm}$, showing that in this region the interference is minor upon the further addition of a second metal ion species. On the other hand, in the region of the ironligand complex absorption $(620 \mathrm{~nm})$, addition of cation $\mathrm{Cu}^{2+}$ is revealed in the form of significant diminishing absorption to almost $50 \%$ (Fig. 8b). The last observation could be the result of the possible competitive interaction between $\mathrm{Fe}^{2+}-\mathrm{Cu}^{2+}$ to the ligand.

Additionally, the previously reported compound 2a [41] with analogous structure, was also tested as sensor for the metal ions described above. Compound 2a is a boronic ester bis-N-bidentate ligand and consequently, the coordination of two metal centers at the same ligand is possible forming more structured complexes (Fig. 9). The UV-Vis analysis reveals that compound 2a also showed colorimetric and 

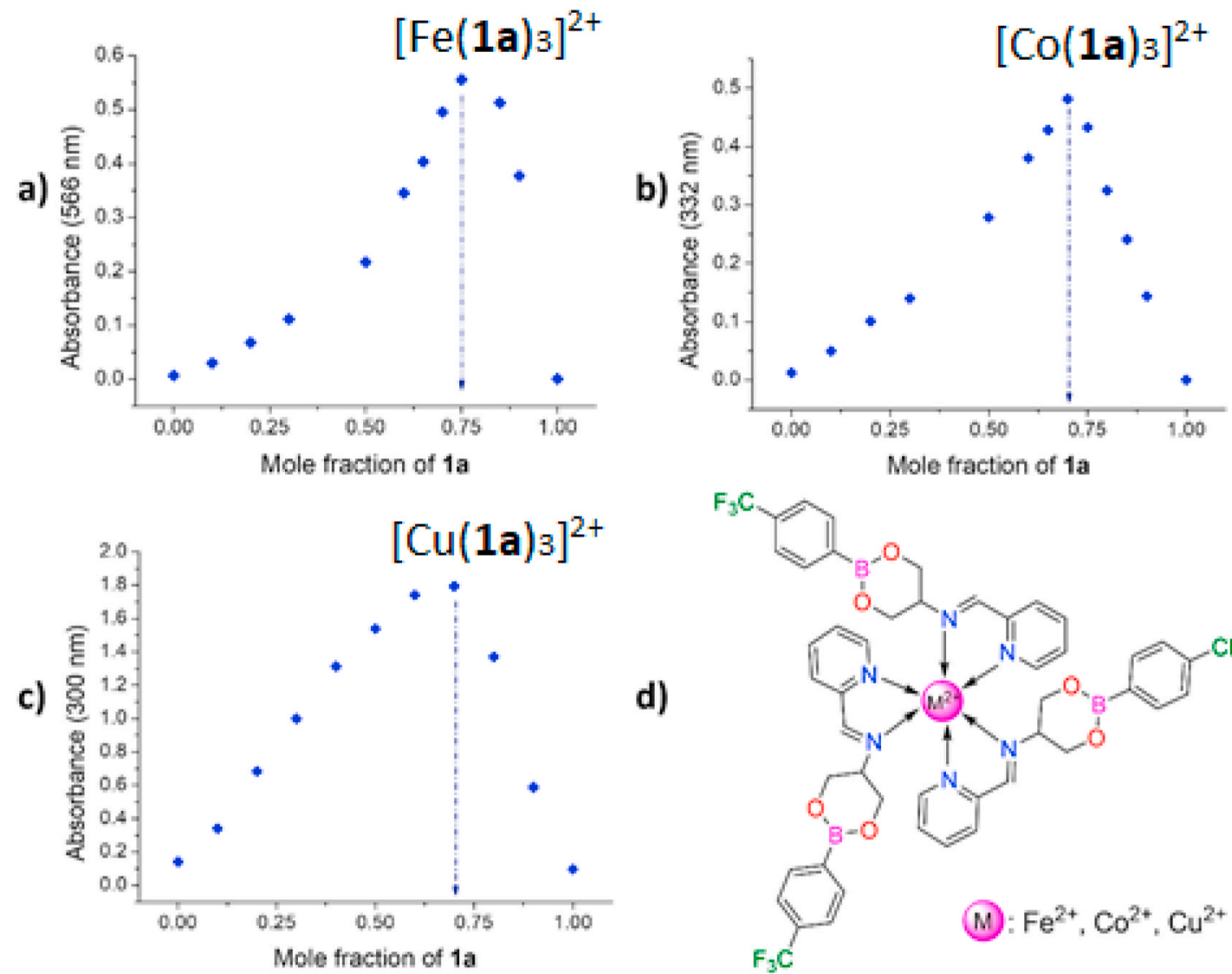

d)

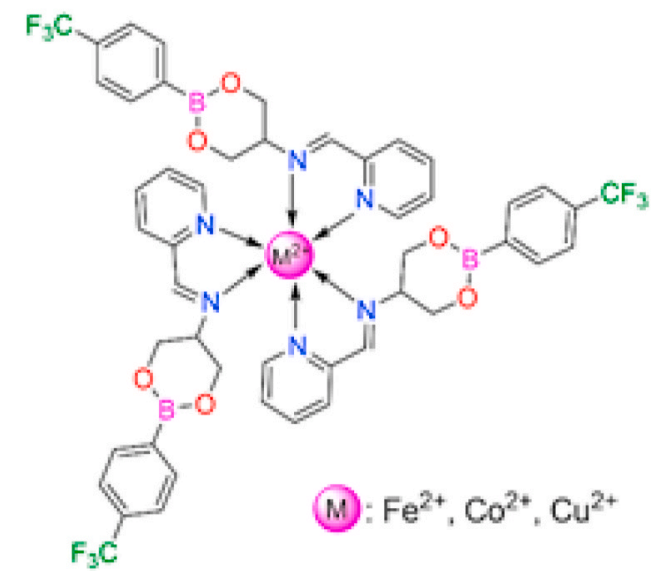

Fig. 7. Job's plots from UV-Vis spectra for compound $1 \mathrm{a}$ with $\mathrm{Fe}^{2+}(\mathrm{a}), \mathrm{Co}^{2+}(\mathrm{b})$ and $\mathrm{Cu}^{2+}(\mathrm{c})$; d) proposed interaction between ligand 1a and metal center.

a)

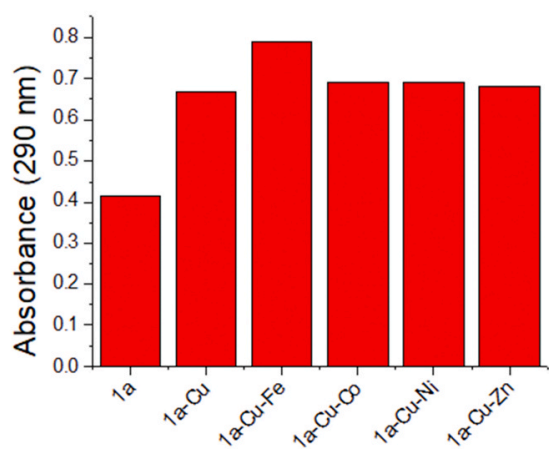

b)

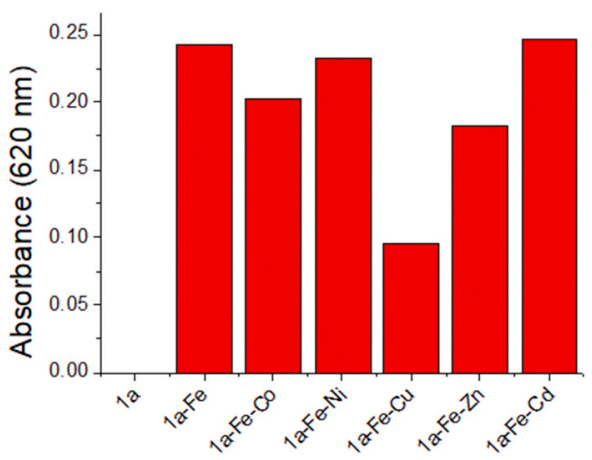

Fig. 8. Absorbance changes at 290 (a) and 620 (b) $\mathrm{nm}$ of $1 \mathrm{a}-\mathrm{Fe}^{2+}$ complex by the metal cation addition in methanol $\left(1 \times 10^{-3} \mathrm{M}\right)$ to each compound. (To $620 \mathrm{~nm}$, the ligand 1a no absorb).

spectral sensitivity in methanol $\left(5 \times 10^{-4} \mathrm{M}\right.$ concentration) towards $\mathrm{Fe}^{2+}, \mathrm{Co}^{2+}$ and $\mathrm{Cu}^{2+}$ cations in 2:3 (metal:ligand) binding stoichiometry. Thus, each metal center interacts with three molecules of $\mathbf{2 a}$ and, each 2a molecule interacts with two metal centers, this stoichiometry has been observed in the formation of polyhedral species of greater complexity as for instance the tetranuclear systems depicted at Fig. 9 [68-71].

Due to the biological and environmental importance of iron and copper, the synthesis of new sensors detecting metals at low concentrations with the smallest detection and quantification limits (LOD and LOQ) is currently of high importance [73,74]. For compounds 1a and 2a, LOD and LOQ values determination was done by using UV-Vis and Fluorescence spectroscopy employing standard deviation and graphic slopes [75-81]. Table 5 shows the LOD and LOQ values obtained for the two compounds using both techniques (Figs. S11-S15). Data from
UV-Vis spectroscopy shows that for compound 1a the sensitivity towards metal cations follows the order $\mathrm{Fe}^{2+}>\mathrm{Cu}^{2+}>\mathrm{Co}^{2+}$, while for $2 \mathrm{a}$ it follows the order $\mathrm{Cu}^{2+}>\mathrm{Co}^{2+}>\mathrm{Fe}^{2+}$. Differences on sensitivity can be attributed to the fact that the bis-imine boronic ester has two chelating sites per ligand and thus, the possibility to form additional metal/ligand species increases, but at the same time, the complexes stability decreases. On the other hand, using the Fluorescence technique, LOD and LOQ values showed that the sensitivity tendency remains as follow $\mathrm{Fe}^{2+}>\mathrm{Cu}^{2+}>\mathrm{Co}^{2+}$ for both compounds, although for compound $1 \mathrm{a}$ the lower values observed indicate a better sensitivity. It is important to remark that the LOD values observed in this work for the cation copper (II), are lower than those reported in the literature using the fluorescence technique (1.25 mM-0.01 mM) [82-86], and even lower that the maximum allowed value in blood $(15.7-23.6 \mu \mathrm{M})$ [87] and in drinking water $(<30 \mu \mathrm{M})[88,89]$ (Figs. S13 and S14). 


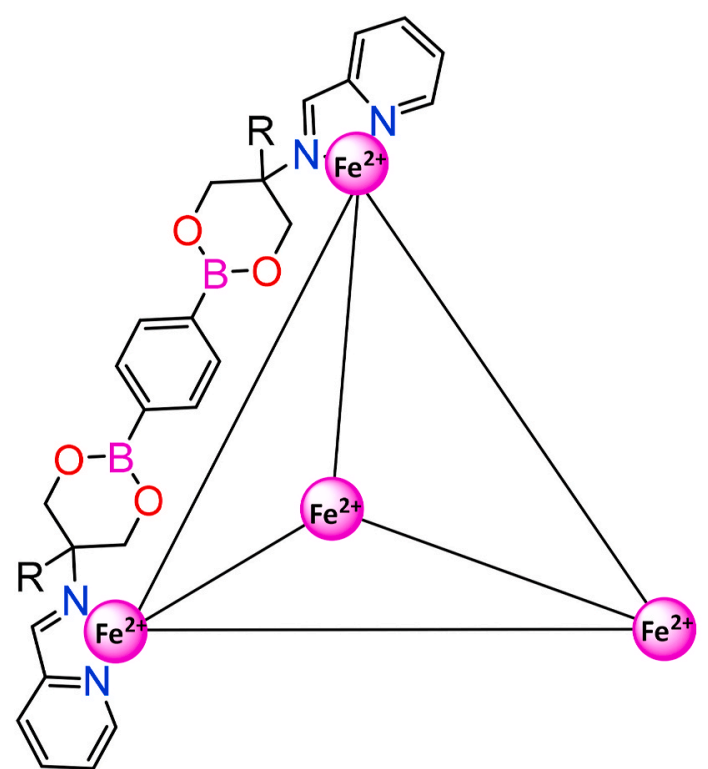

a)

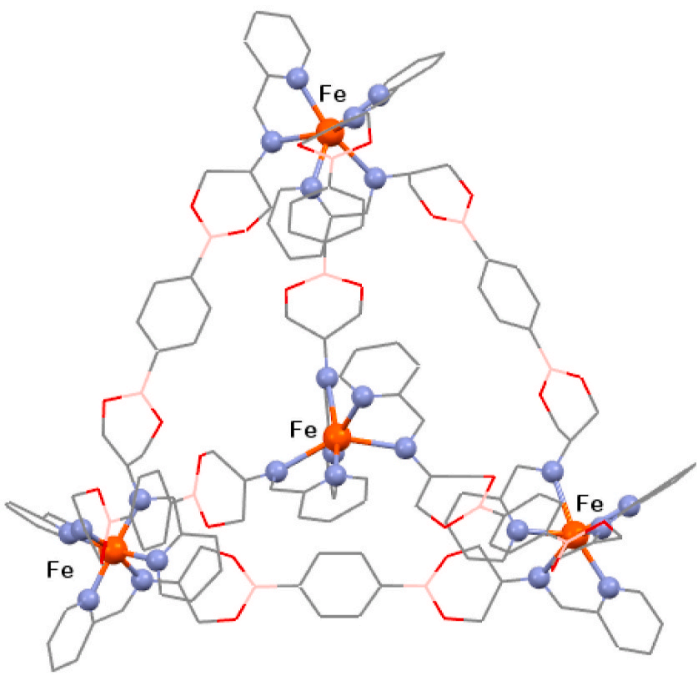

b)

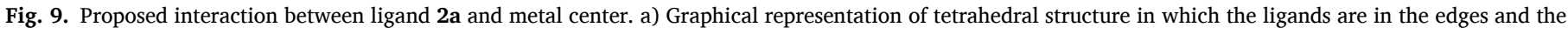
metal centers in the vertices. b) Optimized molecular structure of tetrahedral structure by Spartan [72].

Table 5

LOD and LOQ values determined for compounds $\mathbf{1 a}$ and $\mathbf{2 a}$ toward metal cations.

\begin{tabular}{lllll}
\hline \multicolumn{2}{l}{ UV-Vis Spectroscopy } & & & \\
\hline & & $\mathbf{F e}^{2+}$ & $\mathbf{C o}^{2+}$ & $\mathbf{C u}^{2+}$ \\
\hline \multirow{2}{*}{$\mathbf{1 a}$} & LOD $(\mathrm{mM})$ & 0.48 & 0.94 & 0.85 \\
& LOQ $(\mathrm{mM})$ & 1.45 & 2.86 & 2.58 \\
2a & LOD $(\mathrm{mM})$ & 0.72 & 0.67 & 0.49 \\
\multirow{2}{*}{ Fluorescence } & LOQ $(\mathrm{mM})$ & 2.18 & 2.04 & 1.50 \\
1a & & & & \\
& LOD $(\mu \mathrm{M})$ & 2.66 & 4.37 & 2.89 \\
2a & LOQ $(\mu \mathrm{M})$ & 8.07 & 13.24 & 8.78 \\
& LOD $(\mu \mathrm{M})$ & 12.92 & 15.49 & 15.92 \\
& LOQ $(\mu \mathrm{M})$ & 39.15 & 46.92 & 48.25 \\
\hline
\end{tabular}

As described above, the mixture $1 \mathrm{a}-\mathrm{Fe}^{2+}$ has an intense purple color when it is freshly prepared, nevertheless the color changes over time, indicating instability under normal environmental conditions. Color changes of the $1 \mathrm{a}-\mathrm{Fe}^{2+}$ solution were monitored over $96 \mathrm{~h}$ and are shown in Fig. 10a, during the first $2 \mathrm{~h}$ the color changes from purple to green, later the intensity of color diminishes being almost colorless at the final of the observed period. The UV-Vis spectral changes are shows in Fig. 10b, whereby the band at $566 \mathrm{~nm}$ shown a bathochromic effect (up to $630 \mathrm{~nm}$ ), obtaining a maximum point after $2 \mathrm{~h}$, later this band disappears gradually. At the end, a colorless solution was observed having a wide band around $300 \mathrm{~nm}$. UV-Vis spectral changes indicate that the boron ester and imine groups have been hydrolyzed over the observed period resulting in starting materials. In fact, after $96 \mathrm{~h}$, the final spectrum obtained for the mixture $1 \mathrm{a}-\mathrm{Fe}^{2+}$, corresponds to the spectrum observed for the serinol $/ \mathrm{FeCl}_{2}$ mixture confirming the decomposition of the initial complex (Fig. S16).

Compounds 1a and 2a also were tested as sensors for $\mathrm{Fe}^{3+}$ cation. Therefore, a methanol solution of $\mathrm{FeCl}_{3}$ was added to the methanolic solutions of 1a and 2a. Results showed pale-yellow solutions in both cases being the same as for the only $\mathrm{Fe}^{3+}$ methanol solution (Fig. 11a). Furthermore, UV-Vis spectroscopy analysis for the $\mathrm{Fe}^{3+} / \mathbf{1 a}$ (2a) mixture solutions showed only a broad band at $350 \mathrm{~nm}$ which corresponds to the same observed for free $\mathrm{FeCl}_{3}$ in methanol solution. As mentioned above, a purple color is observed when the ion $\mathrm{Fe}^{2+}$ is used, indicating clearly the selectivity of compounds $\mathbf{1 a}$ and $\mathbf{2 a}$ towards $\mathrm{Fe}^{2+}$, so that these compounds can differentiate $\mathrm{Fe}^{2+}$ from $\mathrm{Fe}^{3+}$ ions in solution (Fig. 11b).

\subsection{Computational calculations}

A computational investigation has been carried out to suggest the role devoted to the methyl group in the stoichiometry observed for metal complexes built up from ligands having the same coordinating capabilities $(\mathbf{1 a}, \mathbf{1 b})$. Due to the large number of possible isomers in the $\mathrm{ML}_{3}$ complexes, the two following assumptions were introduced for the sake of simplifications: (i) the linear (form 1a) or bent (form 1b) conformation of the free ligands is maintained in the complexes. This is reasonable, if the linear $\rightleftharpoons$ bent transformation imply $\mathrm{C}-\mathrm{C}$ chemical bonds to be broken and rebuilt. (ii) the more stable geometry for the $\mathrm{ML}_{3}$ complexes, is not $C_{3}$ in which the three ligands are oriented in the same direction, but rather the geometry in which one ligand is oriented head to tail with the respect to the other ones $\left(C_{1}\right)$. This was confirmed in the case of the iron complexes, in which the $C_{3}$ geometry is located at an average of $1 \mathrm{kcal} / \mathrm{mol}$ above the $C_{1}$ geometry. (iii) the computations were performed on $\mathrm{Fe}^{\mathrm{II}}$ in close shell $d^{6}$ configuration but are applicable to any pseudo-octahedral metal complexes. Under these assumptions and considering methanol as the solvent, to following reactions were considered:

$\left[\mathrm{Fe}(\mathrm{MeOH})_{6}\right]^{2+}+\mathbf{1 a} \rightarrow\left[\mathrm{Fe}(\mathbf{1 a})(\mathrm{MeOH})_{4}\right]^{2+}+2 \mathrm{MeOH}$

$\left[\mathrm{Fe}(\mathbf{1 a})(\mathrm{MeOH})_{4}\right]^{2+}+2 \mathbf{1 a} \rightarrow\left[\mathrm{Fe}(\mathbf{1 a})_{3}\right]^{2+}+4 \mathrm{MeOH}$

The associated changes in the Gibbs free energies $(\Delta G)$ are found to be equal to $-15.8 \mathrm{kcal} / \mathrm{mol}$ and $-17.9 \mathrm{kcal} / \mathrm{mol}$ for (1) and (2) equations, respectively. It is worth pointing out that the conformation of $\mathbf{1 a}$ is the linear transoid form depicted in Scheme 2, in any cases. Interestingly, the same computations carried out for iron-1b complexes lead to $\Delta \mathrm{G}$ values of $-17.0 \mathrm{kcal} / \mathrm{mol}$ and $-12.7 \mathrm{kcal} / \mathrm{mol}$ for the related (1) and (2) equations, respectively. At this stage, and although the replacement of the 6 methanol molecules seems not to be as favorable for $\left[\mathrm{Fe}(\mathbf{1 b})_{3}\right]^{2+}$ than for $\left[\mathrm{Fe}(\mathbf{1} \mathbf{a})_{3}\right]^{2+}$, the overall behavior can be regarded as roughly similar for both $1 \mathrm{a}$ and $\mathbf{1 b}$ based complexes. However, $\left[\mathrm{Fe}(\mathbf{1} \mathbf{a})_{3}\right]^{2+} \mathrm{can}$ be subjected to an additional evolution as follows: 
a)
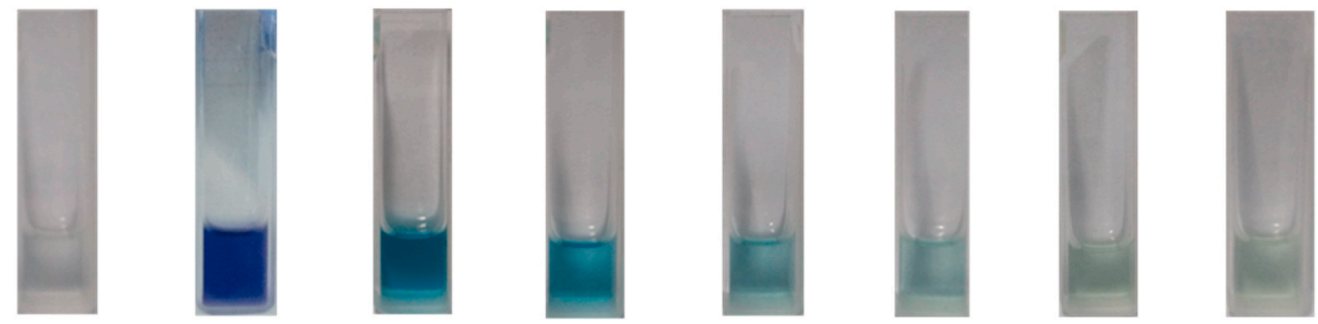

1a

1a-Fe

$2 \mathrm{~h}$

$2.5 \mathrm{~h}$

$24 \mathrm{~h}$

$48 \mathrm{~h}$

$72 \mathrm{~h}$

$96 \mathrm{~h}$

TIME

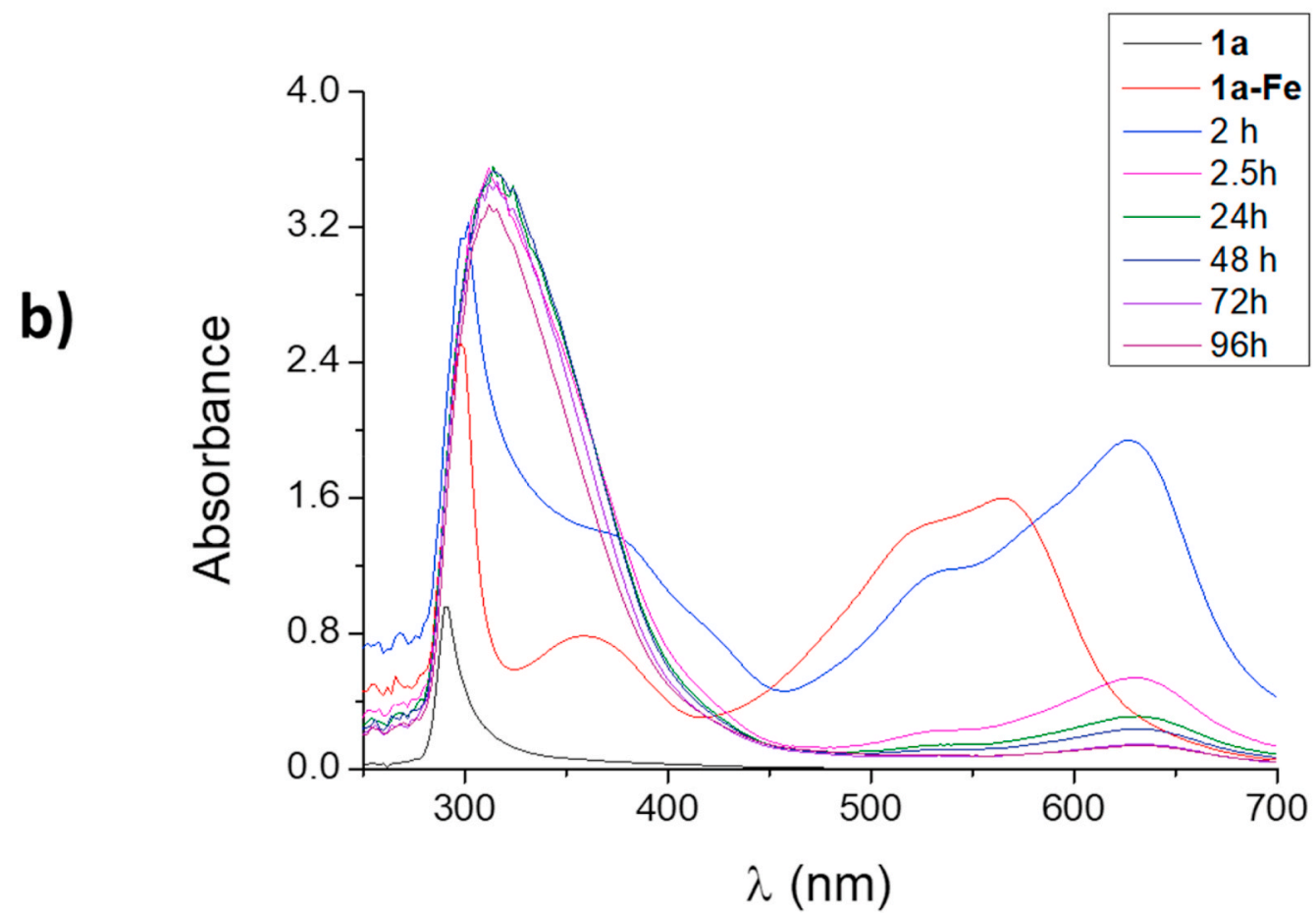

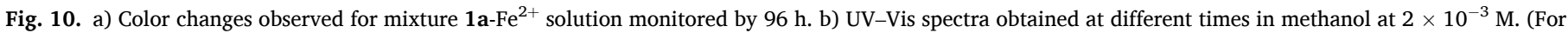
interpretation of the references to color in this figure legend, the reader is referred to the Web version of this article.)

$\left[\mathrm{Fe}(\mathbf{1 a})_{3}\right]^{2+}($ linear transoid $) \rightarrow\left[\mathrm{Fe}(\mathbf{1 a})_{3}\right]^{2+}$ (linear cisoid $)$

The associated $\Delta \mathrm{G}$ value for equation (3) is equal to $-31.8 \mathrm{kcal} / \mathrm{mol}$ which leads to a strong stabilization of $\left[\mathrm{Fe}(1 \mathbf{a})_{3}\right]^{2+}$, this effect cannot take place in $\left[\mathrm{Fe}(\mathbf{1 b})_{3}\right]^{2+}$, leading to total $\Delta \mathrm{G}$ values of $-65.5 \mathrm{kcal} / \mathrm{mol}$ and $-29.7 \mathrm{kcal} / \mathrm{mol}$ for the formation of $\left[\mathrm{Fe}(\mathbf{1 a})_{3}\right]^{2+}$ and $\left[\mathrm{Fe}(\mathbf{1 b})_{3}\right]^{2+}$, respectively. Altogether, the values presented above are all negatives, which suggest that the coordination of three ligand should be possible in any case, one must take them qualitatively as a clear trend towards much better coordinating capabilities in the case of ligand $\mathbf{1 a}$, as observed experimentally. The reason for such difference can be further evaluated based on the computed molecular geometries of the complexes. The averaged $\mathrm{Fe}-\mathrm{N}$ bond length values are gathered in Table 6 . The observation of longer $\mathrm{Fe}-\mathrm{N}$ bond lengths in the proximity of the methyl group $(\mathrm{Fe}-\mathrm{N}=\mathrm{C})$ reflects a steric hindrance in $\left[\mathrm{Fe}(\mathbf{1 b})_{3}\right]^{2+}$. It leads to a distortion of the ideal octahedral symmetry of the $\mathrm{Fe}-\mathrm{N}_{6}$ coordination sphere, and hence to a lowering of the stabilization energy for this species.

In addition, a TD-DFT approach has been used at the B3PW91/6$31 \mathrm{G}^{*}$ level to find a rational for the differences observed in the UV-Vis of spectra of $\mathbf{1} \mathbf{a}-\mathrm{Fe}^{2+}$ and $\mathbf{1 b}-\mathrm{Fe}^{2+}$ complexes, which can be summarized as follows: For 1a: (i) the addition of iron (II) to 1a leads to the gradual appearance of new bands at $360 \mathrm{~nm}$ (weak) and $566 \mathrm{~nm}$ (strong) (Fig. S6a); (ii) the intensity of these bands increases gradually with the concentration of iron added to the solution; (iii) the shape of the spectra remains grossly unaffected. Altogether, these observations suggest that a dominant complex is present in the mixture, the formula of which can tentatively be ascribed to $\left[\mathrm{Fe}(\mathbf{1 a})_{3}\right]^{2+}$. For $\mathbf{1} \mathbf{b}$ : (i) the addition of iron (II) to $\mathbf{1 b}$ leads to the appearance of an intense transition at $380 \mathrm{~nm}$ and a far less intense transition at $535 \mathrm{~nm}$ (Fig. S10); (ii) on going from Fe-1b stoichiometry of $1: 1$ to $1: 3$ a rather small modification of the intensity (absorbance/concentration of metal) is observed; (iii) the shape of the spectra is grossly unaffected by the concentration of ligand. These observations suggest a dominant complex, tentatively ascribed to [Fe (1b) $\left.(\mathrm{MeOH})_{4}\right]^{2+}$.

The computed spectra for $\left[\mathrm{Fe}(\mathbf{1 a})_{3}\right]^{2+},\left[\mathrm{Fe}(\mathbf{1 b})(\mathrm{MeOH})_{4}\right]^{2+}$, and $\left[\mathrm{Fe}(\mathbf{1 b})_{3}\right]^{2+}$ are gathered in Table 7 and compared with the UV-visible data. The shape of the three computed spectra is provided in Fig. S17. In the case of 1a, the shape of the computed spectrum corresponds to the experimental UV-visible spectrum. The discrepancy in energy between theory and experiment is significant at the low energy band $(0.45 \mathrm{eV})$ but still acceptable for an inorganic complex subjected to potential longrange charge transfer effects. The discrepancy becomes more 

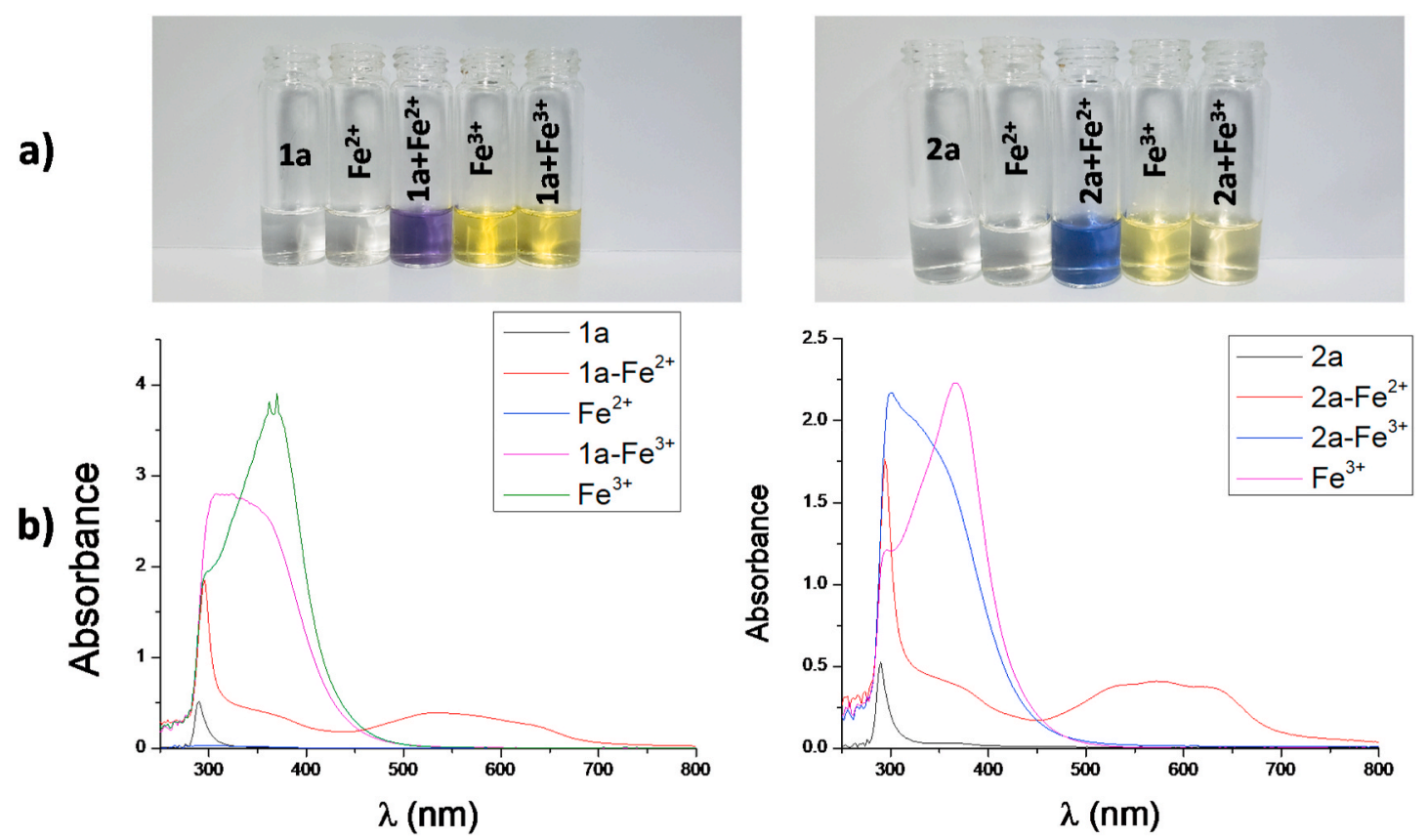

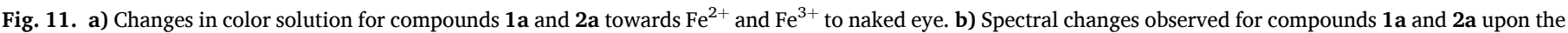

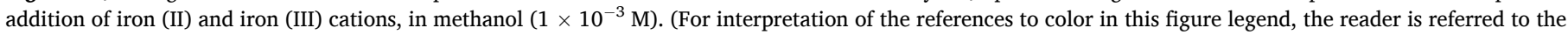
Web version of this article.)

Table 6

Averaged DFT computed Fe-N bond length for $\left[\mathrm{Fe}(\mathbf{1 a})_{3}\right]^{2+}$ and $\left[\mathrm{Fe}(\mathbf{1} \mathbf{b})_{3}\right]^{2+}$.

\begin{tabular}{lll}
\hline & $\mathrm{Fe}-\mathrm{N}_{(\mathrm{py})}$ & $\mathrm{Fe}-\mathrm{N}_{(\mathrm{N}=\mathrm{C})}$ \\
\hline$\left[\mathrm{Fe}(\mathbf{1 a})_{3}\right]^{2+}$ & $2.004 \AA$ & $2.017 \AA$ \\
{$\left[\mathrm{Fe}(\mathbf{1 b})_{3}\right]^{2+}$} & $2.002 \AA$ & $2.178 \AA$ \\
\hline
\end{tabular}

Table 7

Computed data for $\left[\mathrm{Fe}(\mathbf{1 a})_{3}\right]^{2+},\left[\mathrm{Fe}(\mathbf{1 b})(\mathrm{MeOH})_{4}\right]^{2+}$ and $\left[\mathrm{Fe}(\mathbf{1 b})_{3}\right]^{2+}$.

\begin{tabular}{|c|c|c|c|c|c|}
\hline \multirow[t]{2}{*}{ Compound } & \multicolumn{2}{|c|}{ UV-visible } & \multirow[t]{2}{*}{ Compound } & \multicolumn{2}{|c|}{ TD-DFT/6-31G* } \\
\hline & $\lambda_{\max }$ & intensity* & & $\lambda_{\max }$ & $f$ \\
\hline \multirow[t]{2}{*}{$1 \mathrm{a}-\mathrm{Fe}^{2+}$} & 566 & $m$ & \multirow[t]{2}{*}[\mathrm{Fe}(\mathbf{1}\mathbf{a})_{3}]{$^{2+}$} & 467 & 0.167 \\
\hline & 360 & $w$ & & 302 & 0.010 \\
\hline \multirow[t]{4}{*}{$1 b-\mathrm{Fe}^{2+}$} & 535 & $w$ & \multirow[t]{2}{*}[\mathrm{Fe}(\mathbf{1b})(\mathrm{MeOH})_{3}]{$^{2+}$} & 444 & 0.039 \\
\hline & 380 & $\mathrm{~s}$ & & 263 & 0.385 \\
\hline & & & \multirow[t]{2}{*}[\mathrm{Fe}(\mathbf{1}\mathbf{b})_{3}]{$^{2+}$} & 441 & 0.109 \\
\hline & & & & 307 & 0.032 \\
\hline
\end{tabular}

*s, strong; m, medium; w, weak.

pronounced at higher energy transition, which prohibits a detailed analysis of the origin of the electronic effects related to these new transitions. The proposed formula $\left(\left[\mathrm{Fe}(1 \mathbf{a})_{3}\right]^{2+}\right.$ ) appears satisfactory for this specie. In the case of $\mathbf{1 b}$, where two formula may be envisioned, either $\left[\mathrm{Fe}(\mathbf{1 b})_{3}\right]^{2+}$ or $\left[\mathrm{Fe}(\mathbf{1 b})(\mathrm{MeOH})_{4}\right]^{2+}$, it is interesting to observe that the associated computed spectra are significantly different, thus leading to a possible mean to discriminate between the two formulas. Indeed the more intense transition stands at low energy in $\left.[\mathrm{Fe} \mathrm{(1b})_{3}\right]^{2+}$ (like in $\left[\mathrm{Fe}(1 \mathrm{a})_{3}\right]^{2+}$ ), while the intense transition is expected at high energy for $\left[\mathrm{Fe}(\mathbf{1 b})(\mathrm{MeOH})_{4}\right]^{2+}$. With this respect, the experimental spectrum (Fig. S10) is in better agreement with $\left[\mathrm{Fe}(\mathbf{1 b})(\mathrm{MeOH})_{4}\right]^{2+}$, as anticipated and in agreement with the UV-Vis experimental determinations.

\section{Conclusions}

Three imine-boronic esters functionalized with pyridine were synthetized in good yield by condensation reactions. Besides the presence of donor $(\mathrm{N})$ and acceptor (B) atoms, $\mathrm{N} \rightarrow \mathrm{B}$ dative bond formation was not observed because of electronic and steric effects influence. Nonetheless, hydrogen bonds $(\mathrm{C}-\mathrm{H} \cdots \mathrm{O}, \mathrm{C}-\mathrm{H} \cdots \mathrm{N}, \mathrm{C}-\mathrm{H} \cdots \mathrm{F}$ and $\mathrm{C}-\mathrm{H} \ldots \pi)$ are observed in the solid state and support the formation of 2D molecular structure arrangements. The presence of two N-donor coordinating groups (in the compounds) was used for sensing experiments towards metal cations $\mathrm{M}^{2+}$. The colorimetric studies showed that compounds 1a and $2 \mathbf{a}$ are suitable for detection of $\mathrm{Fe}^{2+}, \mathrm{Co}^{2+}$ and $\mathrm{Cu}^{2+}$ ions. The association stoichiometry for ligand 1 a with the metal ions $\left(\mathrm{M}^{2+}\right)$ was determined to be 1:3 (metal:ligand), in contrast with the stoichiometry 1:1 observed when using the ligand $\mathbf{1 b}$. The above behavior was attributed to the linear conformation of the ligand 1a in contrast with the bent "L" geometry observed for ligand $\mathbf{1 b}$ in which the steric effects have an important effect. In addition, the $\Delta \mathrm{G}$ calculated values showed that complex $\left[\mathrm{Fe}(\mathbf{1} \mathbf{a})_{3}\right]^{2+}$ is $35.8 \mathrm{kcal} / \mathrm{mol}$ more stable than the compared value for complex $\left[\mathrm{Fe}(\mathbf{1 b})_{3}\right]^{2}$. Moderate values of LOD and LOQ were observable being for $\mathrm{Cu}^{2+}$ less that the allowed in drinking water. Ligands $\mathbf{1 a}$ and $\mathbf{2 a}$ are suitable to real-time simple-to-use and naked-eye detection of $\mathrm{Fe}^{2+}$ over $\mathrm{Fe}^{3+}$.

\section{CRediT authorship contribution statement}

Paola Sánchez-Portillo: The author certify that all . Aime Hernández-Sirio: and approved the final version of manuscript "Colorimetric Metal Ion (II) Sensor Based on Imine Boronic Esters Functionalized with Pyridine". They warrant that the article is the author's original work, hasn't received prior publication and isn't under consideration for publication elsewhere, The author certify that all, and approved the final version of manuscript "Colorimetric Metal Ion (II) Sensor Based on Imine Boronic Esters Functionalized with Pyridine". They warrant that the article is the author's original work, hasn't received prior publication and isn't under consideration for publication elsewhere, and approved the final version of manuscript "Colorimetric Metal Ion (II) Sensor Based on Imine Boronic Esters Functionalized with Pyridine". They warrant that the article is the author's original work, hasn't received prior publication and isn't under consideration for publication elsewhere, and approved the final version of manuscript 
"Colorimetric Metal Ion (II) Sensor Based on Imine Boronic Esters Functionalized with Pyridine". They warrant that the article is the author's original work, hasn't received prior publication and isn't under consideration for publication elsewhere, and approved the final version of manuscript "Colorimetric Metal Ion (II) Sensor Based on Imine Boronic Esters Functionalized with Pyridine". They warrant that the article is the author's original work, hasn't received prior publication and isn't under consideration for publication elsewhere, and approved the final version of manuscript "Colorimetric Metal Ion (II) Sensor Based on Imine Boronic Esters Functionalized with Pyridine". They warrant that the article is the author's original work, hasn't received prior publication and isn't under consideration for publication elsewhere, and approved the final version of manuscript "Colorimetric Metal Ion (II) Sensor Based on Imine Boronic Esters Functionalized with Pyridine". They warrant that the article is the author's original work, hasn't received prior publication and isn't under consideration for publication elsewhere. Carolina Godoy-Alcántar: The author certify that all . Pascal G. Lacroix: The author certify that all . Vivechana Agarwal: The author certify that all . Rosa Santillán: The author certify that all . Victor Barba: The author certify that all .

\section{Declaration of competing interest}

The authors declare that they have no known competing financial interests or personal relationships that could have appeared to influence the work reported in this paper.

\section{Acknowledgements}

The authors thank Consejo Nacional de Ciencia y Tecnología (CONACyT) for financial support through project No. 33602. This work has been performed within the framework of the LIA-LCMMC FrenchMexican International Laboratory. The authors thank CNRS and CONACYT for financial support.

\section{Appendix A. Supplementary data}

Supplementary data to this article can be found online at https://doi. org/10.1016/j.dyepig.2020.108991.

\section{References}

[1] Severin K. Boronic acids as building blocks for molecular nanostructures and polymeric materials. Dalton Trans 2009:5254-62.

[2] Nishiyabu R, Kubo Y, James TD, Fossey JS. Boronic acid building blocks: tools for self-assembly. Chem Comm 2011;47:1124-50.

[3] Fujita N, Shinkai S, James TD. Boronic acids in molecular self-assembly. Chem Asian J 2008;3:1076-91.

[4] Iwasawa N, Takahagi $\mathrm{H}$. Boronic esters as a system for crystallization- induced dynamic self-assembly equipped with an "on-off" switch or equilibration. J Am Chem Soc 2007;129:7754-5.

[5] Celis NA, Godoy-Alcantar C, Guerrero-Alvarez J, Barba V. Boron macrocycles based on multicomponent assemblies using (3-aminophenyl)boronic acid and pentaerythritol as common reagents; molecular receptors toward Lewis bases. Eur J Chem 2014:1477-84.

[6] Sheepwash E, Zhou K, Scopelliti R, Severin K. Self-assembly for arylboronate esters with pyridyl side chains. Eur J Inorg Chem 2013:2558-63.

[7] Cruz-Huerta J, Salazar-Mendoza D, Hernández-Paredes J, Hernández-Ahuactzi IF, Höpfl H. N-containing boronic esters as self-complementary building blocks for the assembly of 2D and 3D molecular networks. Chem. Com. 2012;48:4241-3.

[8] Salazar-Mendoza D, Cruz-Huerta J, Höpfl H. Macrocycles and coordination polymers derived from self-complementary tectons based on N-containig boronic acids. Cryst Growth Des 2013;13:2441-54.

[9] Stephens AJ, Scopelliti R, Tirani FF, Solari E, Severin K. Crystalline polymers based on dative boron-nitrogen bonds and the quest for porosity. ACS Materials Lett 2019;1:3-7.

[10] Wise MD, Holstein JJ, Pattison P, Besnard C, Solari E, Scopelliti R, Bricogne G, Severin K. Large, heterometallic coordination cages based on ditopic metalloligands with 3-pyridyl donor groups. Chem Sci 2015;6:1004-10.

[11] Jansze SM, Cecot G, Wise MD, Zhurov KO, Ronson TK, Castilla AM, Finelli A, Pattison P, Solari E, Scopelliti R, Zelinskii GE, Vologzhanina AV, Voloshin YZ, Nitschke JR, Severin K. Ligand aspect ratio as a decisive factor for the self-assembly of coordination cages. J Am Chem Soc 2016;138:2046-54.
[12] Jansze SM, Wise MD, Vologzhanina AV, Scopelliti R, Severin K. $\mathrm{Pd}_{2}{ }_{2} \mathrm{~L}_{4}$-type coordination cage up to three nanometers in size. Chem Sci 2017;8:1901-8.

[13] Yildirim M, Kaya I. Synthesis of a novel fluororescent Schiff base as a possible Cu (II) ion selective sensor. J Fluoresc 2010;20:771-7.

[14] Wang L, Ye D, Cao D. A novel Coumarin Schiff-base as a Ni(II) ion colorimetric sensor. Spectrochim Acta Part A 2012;90:40-4.

[15] Gupta YK, Singh AK, Ganjali MR, Norouzi P, Faridbod F, Mergu N. Comparative study of colorimetric sensors based on newly synthesized Schiff bases. Sens Actuator B Chem 2013;182:642-51.

[16] Gupta VK, Mergu N, Kumawat LK, Singh AK. A reversible fluorescence "off-on-off" sensor for sequential detection of Aluminum and Acetate/Fluorine ions. Talanta 2015;144:80-9.

[17] Reimann MJ, Salmon DR, Horton JT, Gier EC, Jefferies LR. Water-soluble sulfonate schiff-base ligands as fluorescent detectors for metal ions in drinking water and biological systems. ACS Omega 2019;4:2874-82.

[18] Luo Q, Bandi KR, Dong Y, Bao H, Li D, Chen Q. Synthesis and living cell imaging of a novel fluorescent sensor for selective cupric detection. Spectrochim Acta, Part A 2019;214:146-51.

[19] Jiang D, Xue X, Zhang G, Wang Y, Zhang H, Feng C, Wang Z, Zhao H. Simple and efficient rhodamine-derived $\mathrm{VO}^{2+}$ and $\mathrm{Cu}^{2+}$ - responsive colorimetric and reversible fluorescent chemosensors toward the design of multifunctional materials. J Mater Chem C 2019;7:3576-89.

[20] Bhaskar R, Kumar GGV, Sivaraman G, Rajesh J, Sareswari S. Fluorescence "turnon" sensor for highly selective recognition of $\mathrm{Cu}^{2+}$ ion and its application to living cell imaging. Inorg Chem Commun 2019;104:110-8.

[21] You GR, Park GJ, Lee SA, Ryu KY, Kim C. Chelate-type Schiff base acting as a colorimetric sensor for iron in aqueous solution. Sens Actuator B Chem 2015;215: 188-95.

[22] Udhayakumari D, Velmathi S. Colorimetric chemosensor for multi-signaling detection of metal ions using pyrrole based Schiff bases. Spectrochim Acta, Part A 2014;225:428-35.

[23] Tg AK, Tekuri V, Mohan M, Trivedi DR. Selective colorimetric chemosensor for the detection of $\mathrm{Hg}^{2+}$ and arsenite ions using Isatin based Schiff's bases; DFT Studies and Applications in test strips. Sens Actuator B Chem 2019;284:271-80.

[24] Gupta VK, Nayak A, Agarwal S, Singhal B. Recent advances on potentiometric membrane pharmaceutical analysis. Comb Chem High Throughput Screen 2011; 14:284-302.

[25] Gupta VK, Mergu N, Kumawat LK, Singh AK. Selective naked-eye detection of Magnesium (II) ions using a coumarin-derived fluorescent probe. Sens Actuator B Chem 2015;207:216-23.

[26] Suksai C, Tuntulani T. Chromogenic anion sensors. Chem Soc Rev 2003;32: 192-202.

[27] Srivastava SK, Gupta VK, Jain S. PVC-based 2,2,2-cryptand sensor for zinc ions. Anal Chem 1996;68:1272-5.

[28] Srivastava SK, Gupta VK, Jain S. Determination of lead using a poly(ninylchloride)based crown ether membrane. Analyst 1995;120:495-8.

[29] Srivastava SK, Gupta VK, Dwivedi MK, Jain S. Cesium PVC-crown (Dibenzo-24crown-8) based membrane sensor. Anal Proc 1995;32:21-3.

[30] Gupta VK, Kumar S, Singh R, Singh LP, Shoora SK, Sethi B. Cadmium (II) ion sensing through p-tert-butyl calix [6]arene based potentiometric sensor. J Mol Liq 2014;195:65-8.

[31] Dehghani MH, Sanaei D, Ali I, Bhatnagar A. Removal of chromium (VI) from aqueous solution using treated waste newspaper as low-cost adsorbent: kinetic modeling and isotherm studies. J Mol Liq 2016;215:671-9.

[32] Gupta VK, Sethi B, Sharma RA, Agarwal S, Bharti A. Mercury selective potentiometric sensor based on low rim functionalized thiacalix [4]-arene as a cationic receptor. J Mol Liq 2013;177:114-8.

[33] Gupta VK, Kumar P. Cadmium (II)-selective sensors based on dibenzo-24-crown-8 in PVC matrix. Anal Chim Acta 1999;389:205-21.

[34] Jain AK, Gupta VK, Sahoo BB, Singh LP. Copper (II)-selective electrode based on macrocyclic compounds. Anal Proc 1995;32:99-101.

[35] Srivastava SK, Gupta VK, Jain S. A PVC-based benzo-15-crown-5 membrane sensor for cadmium. Electroanal 1996;8:938-40.

[36] Guo Y, Wang L, Zhuo J, Xu B, Li X, Zhang J, Zhang Z. A pyrene-based dual chemosensor for colorimetric detection of $\mathrm{Cu}^{2+}$ and fluorescent detection of $\mathrm{Fe}^{3+}$ Tet. Let. 2017;58:3951-6.

[37] Shelaiah M, Wu Y, Singh A, Raju MVR, Lin H. Novel pyrene- and anthracene- based Schiff base derivatives as $\mathrm{Cu}^{2+}$ and $\mathrm{Fe}^{3+}$ fluorescence turn-on sensors and for aggregation induced emissions. J Mater Chem A 2013;1:1310-8.

[38] Cowan JA. Inorganic biochemistry: an introduction. Wiley-VCH; 1997. p. 167-255.

[39] Tapiero H, Townsend DM, Tew KD. Trace elements in human physiology and pathology. Copper, Biomedicine \& Pharmacotherapy 2003;57:386-98.

[40] Sánchez-Portillo P, Arenaza-Corona A, Hernández-Ahuactzi IF, Barba V. Structural analysis of pyridine-imine boronic esters involving secondary interactions on solid state. J Mol Struct 2017:1134:435-43.

[41] Sánchez-Portillo P, Barba V. Bis-imine boronic esters obtained by one step multicomponent reactions. Synthesis and X-ray diffraction structural analysis. Chem. Select. 2017;2:11265-72.

[42] Origin(Pro), Version 8.5.1, Origin Lab Corporation, Northampton, MA, USA

[43] Agilent Technologies. CrysAlisPro, version 1.171.37.35. Oxfordshire, United Kingdom: Yarnton; 2014.

[44] Dolomanov OV, Bourhis LJ, Gildea RJ, Howard JAK, Puschmann H. OLEX2: a complete structure solution, refinement and analysis program. J Appl Cryst 2009; 42:339-41.

[45] Sheldrick GM. Crystal structure refinement with SHELXL. Acta Cryst C 2015;71: $3-8$ 
[46] Macrae CF, Edgington PR, McCabe P, Pidcock E, Shields GP, Taylor R, Towler M, van de Streek J. Mercury: visualization and analysis of crystal structures. J Appl Cryst 2006;39:453-7.

[47] Turner MJ, McKinnon JJ, Wolff SK, Grimwood DJ, Spackman PR, Jayatilaka D, Spackman MA. CrystalExplorer17. University of Western Australia; 2017.

[48] Gaussian 09, Revision 01 D, Frisch MJ, Trucks GW, Schlegel HB, Scuseria GE, Robb MA, Cheeseman JR, Scalmani G, Barone V, Mennucci B, Petersson GA, Nakatsuji H, Caricato M, Li X, Hratchian HP, Izmaylov AF, Bloino J, Zheng G, Sonnenberg JL, Hada M, Ehara M, Toyota K, Fukuda R, Hasegawa J, Ishida M, Nakajima T, Honda Y, Kitao O, Nakai H, Vreven T, Montgomery Jr JA, Peralta JE, Ogliaro F, Bearpark M, Heyd JJ, Brothers E, Kudin KN, Staroverov VN, Kobayashi R, Normand J, Raghavachari K, Rendell A, Burant JC, Iyengar SS, Tomasi J, Cossi M, Rega N, Millam JM, Klene M, Knox JE, Cross JB, Bakken V, Adamo C, Jaramillo J, Gomperts R, Stratmann RE, Yazyev O, Austin AJ, Cammi R, Pomelli C, Ochterski JW, Martin RL, Morokuma K, Zakrzewski VG, Voth GA, Salvador P, Dannenberg JJ, Dapprich S, Daniels AD, Farkas Ö, Foresman JB, Ortiz JV, Cioslowski J, Fox DJ. Wallingford CT: Gaussian, Inc.; 2009.

[49] Tomasi J, Mennucci B, Cammi R. Quantum mechanical continuum solvation models. Chem Rev 2005;105:2999-3093.

[50] Becke AD. Density-functional thermochemistry. III. The role of exact exchange. J Chem Phys 1993;98:5648-52.

[51] Stephens PJ, Devlin FJ, Chabalowski CF, Frisch MJ. Ab initio calculation of vibrational absorption and circular dichroism spectra using density functional force fields. J Phys Chem 1994;98:11623-7.

[52] Hehre WJ, Ditchfield R, Pople JA. Self-consistent molecular orbital methods. XII. Further extensions of Gaussian-type basis sets for use in molecular orbital studies of organic molecules. J Chem Phys 1972;56:2257-61.

[53] Allouche AR. Gabedit - a graphical user interface for computational chemistry softwares. J of Comput Chem 2011;32:174-82.

[54] Patiny L, Borel A. ChemCalc: a building block for tomorrow's chemical infrastructure. J Chem Inf and Model 2013;53:1223-8.

[55] Barba V, Villamil R, Luna R, Godoy C, Höpfl H, Beltran HI, Zamudio LS, Santillan R, Farfán N. Boron macrocycles having a calix-like shape. Synthesis, characterization, X-ray analysis, and inclusion properties. Inorg Chem 2006;45: 2553-61.

[56] Barba V, Bentazos I. Direct synthesis of polymacrocyclic boron compounds: a convenient method for the synthesis of hemicarcerands. J Organomet Chem 2007; 692:4903-8.

[57] Nöth H, Wrackmeyer B. In NMR-basic principles and progress. 1978. p. 14.

[58] Campillo-Alvarado G, Brannam AD, Swenson DC, MacGillivray IR. Exploiting the hydrogen-bonding capacity of organoboronic acids to direct covalent bond formation in the solid state: templation and catalysis of the $[2+2]$ photodimerization. Org Lett 2018;20:5490-2.

[59] Georgiou I, Kervyn S, Rossignon A, De Leo F, Wouters J, Bruylants G, Bonifazi D. Versatile self-adapting boronic acids for H-bond recognition: from discrete to polymeric supramolecules. J Am Chem Soc 2017;139:2710-27.

[60] Rodriguez P, Luna R, Torres A, Bernal MI, Barba V, Höpfl H. On the organizing role of water molecules in the assembly of boronic acids and 4,4'-bipyridine: 1D, 2D and 3D hydrogen-bonded architectures containing cyclophane-type motifs. Cryst Growth Des 2009;9:1575-83.

[61] Hirshfeld FL. Bonded-atom fragments for describing molecular charge densities. Theor Chim Acta 1977;44:129-38.

[62] Wolf SK, Grimwood DJ, McKinnon JJ, Turner MJ, Jayatilaka D, Spackman MA Crystal explorer version 3.1. 2012.

[63] Spackman MA, Jayatilaka D. Hirshfeld surface analysis. Cryst Eng Comm 2009;11: 19-32.

[64] Peralta-Domínguez D, Rodriguez M, Ramos-Ortiz G, Maldonado JL, LunaMoreno D, Ortiz-Gutierrez M, Barba V. A Schiff base derivative used as sensor of copper through colorimetric and surface plasmon resonance techniques. Sens Actuator B Chem 2016;225:221-7.

[65] Maity D, Hari N, Mohanta S. A bis(boronic ester)-based fluorogenic and chromogenic sensor for $\mathrm{F}^{-}$and $\mathrm{Cu}^{2+}$. Chemistry Select 2017;2:9037-45.

[66] Gupta VK, Singh AK, Kumawat LK. Thiazole Schiff base turn-on fluorescent chemosensor for Al3+ ion. Sensor Actuator B 2014;195:98-108.
[67] Peralta-Dominguez D, Rodríguez M, Ramos-Ortiz G, Maldonado JL, MenesesNava MA, Barbosa-Gracía O, Santillan R, Farfán N. A Schiff base derivate from cinnamaldehyde for colorimetric detection of $\mathrm{Ni} 2+$ in water. Sens Actuator B Chem 2015;207:511-51.

[68] Ward MD. Polynuclear coordination cages. Chem Commun 2009:4487-99.

[69] Riddell IA, Hristova YR, Clegg JK, Wood CS, Breiner B, Nitschke JR. Five discrete multinuclear metal-organic assemblies from one ligand: deciphering the effects of different templates. J Am ChemSoc 2013;135:2723-33.

[70] Riddell IA, Ronson TK, Clegg JK, Wood CS, Bilbeisi RA, Nitschke JR. Cation- and anion-exchanges induce multiple distinct rearrangements within metallosupramolecular architectures. J Am Chem Soc 2014;136:9491-8.

[71] Black SP, Stefankiewicz AR, Smulders MMJ, Sattler D, Schalley CA, Nitschke JR, Sanders JKM. Generation of a dynamic system of three-dimensional tetrahedral polycatenanes. Angew Chem Int Ed 2013;52:5749-52.

[72] Spartan'08, Version 1.2.0, Build 132, Wavefuction Inc. Irvine, CA, MA, USA.

[73] Gou S, Liu G, Fan C, Pu S. A new diatylethene-derived probe for colorimetric sensing of $\mathrm{Cu}(\mathrm{II})$ and fluorometric sensing of $\mathrm{Cu}(\mathrm{II})$ and $\mathrm{Zn}$ (II): photochromism and High Selectivity. Sens Actuators, B 2018;266:603-13.

[74] Kim KB, Park GJ, Kim H, Song EJ, Bae JM, Kim C. A novel colorimetric chemosensor for multiple target ions in aqueous solution: simultaneous detection of Mn(II) and Fe(II). Inorg Chem Commun 2014;46:237-40.

[75] Shirivastava A, Gupta V. Methods for the determination of limit of detection and limit of quantification of the analytical methods. Chron Young Sci 2011;2:21-5.

[76] Gupta VK, Maleh HK, Sadegh R. Simultaneous determination of hydroxylamine, phenol and sulfite in water and waste water samples using A voltammetric nanosensor. Int. J. Electrochem. Sci. 2015;10:303-16.

[77] Yola ML, Gupta VK, Eren T, Sen AE, Atar N. A novel electro analytical nanosensor base don graphene oxide/silver nanoparticles for simultaneous determination of quercetin and morin. Electrochim Acta 2014;120:204-11.

[78] gupta VK, Goyal RN, Sharma RA. Comparative studies of neodymium (III)-selective PVC membrane sensors. Anal Chim Acta 2009;647:66-71.

[79] Goyal RN, Gupta VK, Chattarjee S. Fullere- $C_{60}$-modified edge plane pyrolytic graphite electrode for the determination of dexamethasone in pharmaceutical formulations and human biological fluids. Biosens Bioelectron 2009;24:1649-54.

[80] Goyal RN, Gupta VK, Chatterjee S. A sensitive voltammetric sensor for determination of synthetic corticosteroid triamcinolone, abused for doping. Biosens Bioelectron 2009;24:3562-8.

[81] Maleh HK, Javazmi FT, Atar N, Yola L, Gupta VK, Ensafi AA. A novel DNA biosensor based on a pencil graphite electrode modified with polypyrrole/ functionalized multiwalled carbon nanotubes for determination of 6-mercaptopurine anticancer drug. Ind Eng Chem Res 2015;54:3634-9.

[82] Xiang Y, Li Z, Chen X, Tong A. Highly sensitive and selective optical chemosensor for determination of $\mathrm{Cu}^{2+}$ in aqueous solution. Talanta 2008;74:1148-53.

[83] Carlos F, Nunes MC, Boni L, Machado GS, Nunes FS. A novel fluorene-derivative Schiff-base fluorescent sensor for copper (II) in organic media. J Photochem Photobiol, A 2017;348:41-6.

[84] Zhao M, Yang X-F, He S, Wang L. A rhodamine-based chromogenic and fluorescent chemosensor for copper ion in aqueous media. Sens Actuator B Chem 2009;135: 625-31.

[85] Singh Y, Arun S, Singh BK, Dutta PK, Ghosh T. Colorimetric and ON-OFF-ON fluorescent chemosensor for the sequential detection of $\mathrm{Cu}(\mathrm{II})$ and cysteine and its application in imaging of living cells. RSC Adv 2016;5:80268-74.

[86] Wagh YB, Kuwar A, Sahoo SK, Gallucci J, Dalal DS. Highly selective fluorimetric sensor for $\mathrm{Cu}^{2+}$ and $\mathrm{Hg}^{2+}$ using a benzothiazole-based receptor in semi-aqueous media and molecular docking studies. RSC Adv 2015;5:45528-34.

[87] Gupta VK, Singh LP, Singh R, Upadhyay N, Kaur SP, Sethi B. A novel copper (II) selective sensor based on Dimethyl 4,4'(o-phenylene)bis (3.thioallophanate) in PVC matrix. J Mol Liq 2011;174:11-6.

[88] Rathod V, Bera S, Singh M, Mondal D. A colorimetric and flourometric investigation of $\mathrm{Cu}(\mathrm{II})$ ion in aqueous medium with a fluorescein-based chemosensor. RSC Adv 2016;5:34608-15.

[89] Lin Q, Chen P, Liu J, Fu Y, Zhang Y, Wei T. Colorimetric chemosensor and test kit for detection copper(II) cations in aqueous solution with specific selectivity and high sensitivity. Dyes Pigments 2013;98:100-5. 